\title{
A Qualitative Study on Experiences and Needs of Language Sample Analysis by Speech-Language Pathologists: Focused on Children with Language Disorders
}

\author{
So Jung $\mathrm{Oh}^{\mathrm{a}}$, Ji Hye Yoon ${ }^{\mathrm{b}}$, YoonKyoung Lee ${ }^{\mathrm{b}}$ \\ ${ }^{a}$ Department of Communication Disorders \& Audiology, Tongmyong University, Busan, Korea \\ ${ }^{b}$ Division of Speech Pathology and Audiology, Hallym University, Chuncheon, Korea
}

Correspondence: YoonKyoung Lee, $\mathrm{PhD}$ Division of Speech Pathology and Audiology, College of Natural Sciences, Hallym University, 1 Hallymdaehak-gil, Chuncheon 24252, Korea Tel: +82332482219

Fax: +82332563420

E-mail: ylee@hallym.ac.kr

Received: April 20, 2020

Revised: May 9, 2020

Accepted: May 9, 2020

This work was supported by the Ministry of Education of the Republic of Korea and the National Research Foundation of Korea (NRF2019S1A5A2A03052093)

\begin{abstract}
Objectives: Language sample analysis has been the "golden standard" in language assessment for children. The purpose of this study is to examine opinions of SLPs on their experiences with children's language analysis and to find alternatives that could make the analysis more useful and robust. Methods: Eight SLPs with experience in language sample analysis participated in in-depth interviews on the needs, implementation, and obstacles of language sample analysis in child language evaluation and intervention. Interviews were conducted individually with the first researcher based on the questionnaire developed by the researchers, and the interviews were recorded and transcribed and coded according to the qualitative research method. Results: As a result of qualitative analysis by transferring the contents of the interview, 2 topics and 8 sub-themes were derived for the current state of utterance analysis, and 4 topics for the alternatives to utterance analysis and 11 topics accordingly. Conclusion: All experts recognized the need for utterance analysis, but noted that there were practical difficulties in conducting utterance analysis in clinical settings. In order to properly realize the value of speech analysis in children's language evaluation, three things need to be developed; systematic sampling procedures, objective analysis using natural language processing technology, and norms and criteria through accumulation of sufficient language sample data for various age groups.
\end{abstract}

Keywords: Language sample analysis, Child language, Qualitative research, Natural language processing, Computerized language analysis 언어표본분석(language sample analysis)은 오랫동안 연구자나 임상가들에게 표현언어능력을 평가하는 표준(golden standard) 절 차로 여겨져 왔다(Bloom \& Lahey, 1978; Miller, Andriacchi, \& Nockerts, 2016; Miller, 1981). 국내외 언어장애의 평가에 관한 교재 및 문헌들에서도 발화를 유도하고 수집하는 방법이나 의미, 구문, 화용영역의 분석을 실시하는 방법 등을 상당한 비중으로 다루고 있고 언어발달장애 등의 과목에서 발화를 분석하는 방법에 대한 이론 수업과 실습을 거치게 된다. 임상실습에서도 발화 분석을 실 시하여 보고서 양식은 이러한 발화 분석을 염두에 두고 영역별로
공식검사 결과와 더불어 발화를 분석한 내용, 행동 관찰 사항을 차 례로 기술하도록 되어 있다(Kim, 2014; Nelson, 2009; Paul \& Nobury, 2012).

언어표본분석은 비공식적 절차라는 점, 규준에 의한 상대적 비 교보다는 연령이나 발달에 따른 준거 수행 여부를 관찰하고 기술 하는 평가라는 점, 또 탈맥락적인 언어검사들과는 달리 비교적 자 연스러운 상황에서의 언어행동을 관찰할 수 있다는 점 때문에 공 식적 절차인 표준화 검사와 자주 비교되어왔다. 발화 분석과 함께 주요 언어평가 절차 중 하나인 표준화 언어검사도구에 대해서는 진 
단정확도(민감도와 특이도) 문제나 표본(sample) 구성에서의 언어 적, 문화적 편향성 등의 문제가 제기되어 왔다(Betz, Eickhoff, \& Sullivan, 2013; McCabe \& Champion, 2010). 이에 비해 언어표본 분석은 대표성 있는 표본 수집만 가능하다면 자연스러운 상황에 서 대상자의 언어능력을 파악할 수 있으며, 어떠한 강점과 약점을 가지는지 등의 구체적이고 자세한 평가가 가능하다는 이점이 있다 고 보고되었다(Sticker, 1987). 또, 다른 비공식 평가 절차인 보호자 면담이나 역동적 평가에 비교해서도 자연스러운 상황에서 아동의 실제 언어행동을 직접 관찰할 수 있다는 장점을 가진다(Paul \& Norbury, 2012).

어떻게 하면 대표성 있고 자연스러운 발화 표본을 구할 수 있는 지 표본 수집 과제나 분석 절차, 발화 샘플의 크기, 대화 상대방 같 은 발화 표본 수집 조건에 대해서도 논의가 활발히 이어져왔다. 발 화 수집 과제로는 대화와 이야기/내러티브 산출 과제, 설명하기 과 제, 그림 기술하기 등의 과제가 주로 사용되어 왔으나 하나의 과제 가 다른 과제에 비해 낫다고 보고되기 보다는 대상자의 연령에 따 라 적절한 과제를 적용하거나 복수의 과제를 선택하는 것이 권고되 었다. 연령 별로는 학령전기 아동의 경우 내러티브 과제가 유용하 고, 설명하기(expository) 과제가 복문산출 기회가 많아 학령기 이 후 연령에 적절한 것으로 보고되었다(Nippold et al., 2014; Scott \& Winsor, 2000). 발화 길이로는 전통적으로는 100 개 발화나(Scarborough, 1990), 50개 발화(Owens, 2014; Yoon, Kim, Kim, Chang, \& Cha, 2013)가 어휘나 구문을 살펴보기에 타당하다고 보고되기 도 하였으나 좀더 짧은 샘플로도 양호한 분석 신뢰도를 보고하는 연구도 있었다(Heilmann et al., 2008).

의사소통 기능을 살펴보기 위해 간혹 언급되는 몇몇 발화 수집 절차를 사용하는 경우를 제외하면 국내에서는 주로 언어재활사가 스스로 고안한 발화 수집 절차로 발화를 수집하고 분석하고 있는 데 반해, 해외에서는 LARSP (Language Assessment Remediation and Screening Procedure; Crystal, Fletcher, \& Garman, 1989), DSS (Developmental Sentence Scoring; Lee, 1974), IPSyn (Index of Productive Syntax; Scarborough, 1990), SUGAR (Sampling Utterances and Grammatical Analysis Revised; Pavelko \& Owens, 2017) 등의 다양한 표준화된 발화수집 및 분석 체계가 사용되고 있다. 더 나아가 발화 분석 체계를 컴퓨터화한 프로그램들도 보편적으로 사 용되고 있는데 SALT (Systematic Analysis of Language Transcripts; Miller \& Iglesias, 2015)나 CLAN (Computerized Language Analysis; MacWhinney, 2000) 등이 대표적인 예이다. 이러한 컴퓨터 언 어 분석 프로그램들은 발화 자료를 지속적으로 축적하여 규준이 나 분석법을 꾸준히 업데이트하고 있다. 최근에는 소형 녹음기를
이용해 일상생활에서의 언어 환경 전체를 기록하고, 양육자의 말 과 아동의 발성, 대화 차례, 심지어 TV 등을 구분하여 전사, 측정할 수 있는 LENA (Language Environment Analysis system; Xu, Yapanel, Gray, \& Baer, 2008)가 상용화되어 있다. 국내에서는 컴퓨터 언 어분석 소프트웨어 프로그램으로 KCLA (Pae, 2000)가 개발되었 으나 널리 사용되진 못한 상태에 있다가 최근 KLA (Korean Language analysis)라는 이름으로 개정되었으나 상용화되지는 않은 채 일부 연구에 활용되는 정도에 그치고 있다( $\mathrm{Ha}, \mathrm{Seol}, \mathrm{So}, \& \mathrm{Pae}, 2016)$. 언어발달이나장애 연구에서는 의미(Song et al., 2015), 구문(Finestack, Rohwer, Hilliard, \& Abbeduto, 2020; Han \& Yim, 2016), 상 호작용(Yim, Park, Cheon, Lee, \& Lee, 2015), 조음 등 각 영역별로 발화표본분석이 활발히 사용되고 있으나 정작 언어치료 임상현장 에서는 보편적으로 사용되지 못하고 있는 경우가 있음이 몇몇 현 장 설문 연구를 통해 보고되었다. 연구에 따라 임상가들이 발화 분 석을 실시한다고 응답한 비율에 큰 편차를 보였다. 취학 전 아동을 주로 치료하는 미국의 언어임상가들을 상대로 조사한 Kemp와 Klee (1997)에서는 대다수의 응답자가 발화 분석을 실시한다고 보 고하고 $15 \%$ 정도만 평가에서 언어표본분석을 실시하지 않는다고 대답한 반면, Pavelko, Owens JR, Ireland 그리고 Hahs-Vaughn (2016)의 연구에서는 대부분의 학교 근무 언어재활사들은 $67 \%$ 가 사용한다고 보고하였으나 이들이 연간 분석하는 발화 표본의 수 는 대부분 10 개 미만이라고 대답하였다. 발화 분석을 실시하지 않 는 이유로는 시간이 너무 많이 걸려서'라는 응답이 가장 많았고, 컴 퓨터 자원 부족, 전문성 결여, 금전적 제약 등을 꼽았다(Kemp \& Klee, 1997). 또, 발화 수집 시 매우 제한적인 발화만을 수집하여 그 자리에서 실시간으로 바로 전사하고 표본을 녹화, 녹음하지 않거나 기존의 개발, 확립된 표준화된 프로토콜보다 본인이 고안한 절차대 로 발화표본을 수집하여 분석하고 직접적으로 복문을 유도하는 등의 근거기반 실제에 어긋나는 양상을 보이기도 하였다.

국내에서도 언어재활사를 대상으로 대규모 설문연구에서 평가 에서 언어표본분석을 사용한다고 보고한 참여자의 비율은 절반에 못 미치는 수준이었으며, 평가의 가장 중요한 목적이 치료계획을 세우기 위함이라고 보고하면서도 가장 많이 사용한다고 보고한 평 가 절차는 표준화검사였다(Lee, Oh, Yoon, \& Choi, in press). 표준 화된 검사보다 자연스러운 상황에서의 언어표본분석이 권고되는 다문화가정 아동의 평가에서도 발화 분석보다는 표준화 언어검사 를 절대적으로 많이 사용되고 있다고 보고되기도 하였다(Korean Institute for Healthy Family, 2012). 언어 평가에서 언어표본분석 의 중요성은 선행연구나 문헌에서 이견 없이 언급되어 왔고(Evans, 1996), 특히 언어발달이 급격하게 이루어지는 아동 대상 평가나 중 
재 과정에서는 발달을 확인하고 중재에 따른 변화 정도를 확인하기 위한 발화 분석의 필요성이 증가된다고 볼 수 있다. 임상현장에서 언어표본분석이 보다 보편적이고 일상적으로 사용되기 위해서는 일단 수집과 분석을 실시하는 언어치료 임상가들이 발화 분석을 어떻게 인식하고 있으며, 어느 정도 실제 실시하고 있는지, 그 과정 에서 경험하는 어려움은 없는지 등을 살펴볼 필요가 있다.

본 연구에서는 아동언어장애 사례에 경험이 있는 언어재활사들 을 대상으로 언어표본분석에 대해서 갖고 있는 인식과 현재 임상 에서 사용하고 있는 현황과 그에 따른 어려움, 발화 분석 관련한 요 구나 개선점은 무엇인지 전문가 심층 면담을 통하여 알아보고자 한다. 언어재활사들의 발화 분석 경험이나 인식에 대하여는 아직까 지 연구가 거의 없으므로 아직까지 알려진 바가 없는 분야에 대해 실제적인 탐색을 하는 데에 적합한 질적 연구 방법을 적용하였다 (Strauss \& Corbin, 2001). 사용현황이나 문제를 단편적으로 묻고 응답결과를 제시하기 보다는 전문가들의 주관적인 경험과 인식을 깊이 있게 살펴볼 수 있는 면담 자료 분석에서 예상되는 어려움이 나 문제들이 어떤 관련을 가지고 나타나는지 혹시 있을 어려움이 있다면 이를 깊이 있게 통찰하고 이해하고 그 원인이나 대안을 깊 이 있게 모색할 수 있을 것으로 판단하였다. 따라서 본 연구에서는 아동언어평가와 발화 분석에 대한 직접 경험이 있는 언어재활사들 을 대상으로 언어표본분석의 의의나 필요성에 대한 인식을 살펴보 고, 언어치료 현장에서 언어표본분석이 어느 정도 실시되고 있으 며, 이에 수반되는 어려움은 무엇인지 알아보려고 한다. 마지막으로 발화 자료를 심층 분석하여 발화 분석에 대한 어려움들이 서로 어 떤 관련을 맺고 특성을 가지는지 이해하고 개선 요구사항을 종합 하여 가능한 대안을 심도 있게 모색해 봄으로써 이후 양적, 실증적 연구의 기초 자료를 제공할 수 있을 것이다.

\section{연구방법}

\section{면담 참여자}

본 연구는 아동언어장애 치료 전문인 언어재활사 8 명을 대상으 로 하였다. 언어재활사의 경우는 언어병리학 학사학위 이상을 소지 하고 있는 1-2급 언어재활사로, 언어치료 실무경력이 2년 이상이고 아동언어장애를 진단하고 치료한 경험이 있는 사람으로, 현재 아 동을 대상으로 평가와 중재 서비스를 전문적으로 제공하는 기관 에 근무하고 있으며, 최근 6 개월 이내에 아동 언어를 평가한 경험이 3 사례 이상인 사람으로 정하였다. 연구자는 조건을 만족하는 언어 재활사를 직접 섭외 혹은 주변을 받아 연락하였으며 이중에 최종 8 명이 연구에 참여하였다. 학력이 학부 졸업부터 박사까지, 경력은 2
Table 1. Participants' information

\begin{tabular}{|c|c|c|c|c|c|c|}
\hline No. & Degree & $\begin{array}{l}\text { Certifi- } \\
\text { cate level }\end{array}$ & Gender & $\begin{array}{l}\text { Age } \\
\text { (yr) }\end{array}$ & $\begin{array}{c}\text { Clinical } \\
\text { career (yr) }\end{array}$ & Work setting \\
\hline S1 & Master's & 1 & $\mathrm{~F}$ & 45 & 20 & Private center/hospital \\
\hline S2 & Master's & 1 & $\mathrm{~F}$ & 40 & 12 & Private center \\
\hline S3 & Master's & 1 & $\mathrm{~F}$ & 49 & 23 & Private center \\
\hline S4 & Bachelor's & 2 & $\mathrm{~F}$ & 26 & 2 & Private center \\
\hline S5 & Doctoral & 1 & $\mathrm{~F}$ & 44 & 20 & Hospital \\
\hline S6 & Doctoral & 1 & $F$ & 44 & 22 & University \\
\hline S7 & Doctoral & 1 & $\mathrm{~F}$ & 43 & 15 & University \\
\hline S8 & Master's & 1 & $\mathrm{~F}$ & 28 & 4 & Hospital \\
\hline
\end{tabular}

$y r=$ year.

년부터 20 년까지 다양한 치료사를 섭외하였다. 이 중 2 명은 10 년 이 상의 치료 경력 후에 대학교에서 언어 분석을 강의하고 있는 사람 이었다. 면담 질문 선정을 위해 예비 면담에 참여한 1 명을 제외하고 선정된 8 명의 전문가에 대한 정보는 Table 1과 같다.

\section{연구절차}

면담 질문지 작성

먼저 자발화 분석에 대한 설문이나 현황연구 등 관련된 선행연 구를 분석하고 그 결과에 근거하여 1 차 질문지를 개발하였다. 1 차 적으로 구성된 질문지를 가지고 3 명의 공동연구자가 모여 유사한 항목을 통합, 조정하고 전환 질문을 보강하였으며 발화 분석 현황 에 대한 질문을 추가 보완하여 최종 질문지를 완성하였다. 질문지 는 반구조화된 질문으로 구성하였다. 질문 항목은 대상자의 자격 증 현황, 근무 현황 및 주 담당 사례 등의 기본정보로 시작하여 본 격적인 면담으로 전환하기 위한 전환 질문 항목으로 사례 특성, 진 단 · 평가 및 중재 비율, 현재 사용하고 있는 공식 및 비공식 평가 절 차들의 장단점을 포함하였다. 이후 핵심질문 부분에서는 영역/연 령/장애 별 평가 내용, 발화 분석 실시 현황과 어려움 및 개선할 수 있는 방안, 요구사항 등의 항목을 포함하였다. 마지막으로 발화 분 석과 관련하여 추가로 언급하고 싶은 것과 해외나 국내에서 실시되 고 있는 컴퓨터 언어분석 시스템에 대한 사용 경험과 인식에 대한 질문으로 질문지를 구성하였다. 이후 1 명의 언어재활사에게 1 차로 개발된 질문지로 예비면담을 실시하여 질문의 내용과 면담 방법에 대하여 피드백을 구하였고, 이를 토대로 연구자들이 논의하여 질 문 내용을 일부 보완하였다.

\section{면담 실시 및 기록}

대상자 면담은 2019년 12월부터 2020년 1월까지 진행하였다. 면 담은 제 1 연구자가 모두 실시하였고, 면담 대상자의 직장을 방문하 
여 실시하거나 근처 조용한 장소에서 면담을 실시하였다. 면담 시작 전 대략적인 질문 내용과 주제에 대하여 알려주었고, 면담 대상자 가 충분히 의견을 피력할 수 있도록 면담 시간에 제한을 두지는 않 았다. 면담 시간은 총 1 시간 30분-2시간 정도였으며, 20-30분간의 라포형성을 위한 시간을 제외한 순수 면담 시간은 1시간-1시간 30 분 정도였다. 면담 시 면담 대상자의 동의 하에 면담 내용을 Apple Iphone 6의 녹음 앱을 이용하여 녹음하였다. 녹음 내용은 면담을 실시한 이후 3-5일 이내에 전사하였으며, 완성된 전사본을 분석한 후 필요한 경우 대상자에게 추후 확인 면담 과정을 거쳐 결과를 정 리하였다. 이러한 과정을 거쳐 모든 면담 내용이 11 point 줄간격 $160 \%$ 로 정렬하였을 때 A4 용지 약 107 장으로 전사되었다.

\section{자료분석}

전사된 자료는 질적 분석 방법의 하나인 근거이론의 연속적 비 교법(constant comparative method)에 따라 부호화(coding)하였 고, 부호(codes)들 간의 연속적인 비교를 통해 범주와 주제를 도출 하였다(Lincoln \& Guba, 1985).

먼저 8 개의 전사본 중 2 개를 임의로 선정하여 제 1 연구자와 공동 연구자 2 명이 독립적으로 코딩한 후 함께 모여 논의를 거쳐 첫 번째 코드북(codebook)을 작성하였다. 그 다음 전사본을 첫 번째 코드 북의 코드들을 이용하여 코딩하고 기존의 코드들을 통합 또는 분 리하거나 새로운 코드를 생성하는 과정을 거쳐 두 번째 코딩북을 작성하였다. 이러한 과정을 거친 결과, 최종적으로 3 개의 부호집이 작성되었고, 관련된 부호들을 범주로 묶고 범주들을 다시 묶고 분 류하여 발화분석 현황에 대하여 2 개 주제와 그에 따른 8 개 소주제 를 도출하였으며, 발화 분석에 대안에 대하여 4 개 주제와 그에 따 른 11 개 소주제를 도출하여 총 6 개의 주제와 19 개의 하위 주제가 도출되었다.

주제 도출과정에서 새로이 중요성이 부각된 질문 내용에 대해 일 부 면담 대상자들에게 추후 온라인 면담을 실시하였고, 질적 분석 이 모두 끝난 후, 연구 결과를 요약하여 1 명의 면담자에게 확인 면 담을 실시하였다. 확인 면담의 대상자는 결과 요약 보고서에 중요 한 사항들이 빠짐없이 포함되어 있으며 동의할 수 없는 부분이 없 다고 응답하였다. 또한 연구 절차에 관련하여 특별히 개선되어야 할 사항이 없었다고 응답하였다.

\section{질적 연구의 신뢰도와 타당도 확보를 위한 노력}

본 연구에서는 질적 분석 결과의 신뢰도와 타당도를 높이기 위 해 다음과 같은 방법을 사용하였다. 첫째, 아동언어장애 평가 경험 이 많은 언어재활사들을 대상으로 하였으며, 다양한 학력과 경력
의 언어재활사들을 면담자로 섭외하였다. 둘째, 제 1 연구자가 모든 면담을 실시하고 모든 연구자가 함께 인터뷰 질문을 구성하였다. 셋째, 연구자들이 각자 2-3명의 자료를 독립적으로 분석한 뒤 모여 공통되는 키워드와 코드로 1차 코딩북을 작성하였고 이후 3 차례 의 온·오프라인 미팅을 통해 최종 코딩북을 제작하였다. 셋째, 면 담 내용의 분석 자료를 가지고 참여자들에게 추후 확인하여 연구 자들의 주관적 해석의 위험을 피하고 신뢰성을 확보하고자 하였다 (Mexwell, 2004).

\section{연구결과}

질적 연구 분석 절차를 거친 자료들에서 발화 분석의 현황에 대 하여 2 개 주제와 그에 따른 8 개 하위 주제를 도출하였으며 발화 분 석에 대안에 대하여 4 개 주제와 그에 따른 11 개 하위 주제로 정리하 였다. 이를 도식화하여 Figure 1에 제시하였다.

\section{발화 분석 실시 현황}

발화 분석의 필요성 인정

면담 참여자들은 대체로 발화 분석의 필요성에는 공감하고 있었 다. 다만 현재 많이 사용하고 있는 평가 절차로는 표준화 검사도구 를 언급하였는데 이에 대해서는 다른 전문가들과의 의사소통이나 양육자에게 아동의 문제를 인식시키고 중재 필요 여부를 판단하는 데 도움이 되기 때문이라고 언급하였다. 하지만 대상자의 전반적인 언어능력을 자세히 살펴보거나 질적인 양상을 살펴보기 위해서는 자발화 분석이 필요하다는 점은 공통적으로 언급하였다.

\section{표준화 검사의 한계보완}

전문가들은 표준화 검사가 객관성과 신뢰성 있는 검사도구로 양 육자나 다른 전문가들과의 의사소통에 효과적이라는 장점을 언급 하였지만 그것만으로는 언어평가에 부족할 수 있다는 점을 모두 언 급하였다. 덧붙여 현재 우리나라의 아동기 표준화 언어 검사도구들 의 규준이 너무 오래 전 자료에 근거하고 있으며 검사 문항내용이 시대에 맞지 않는 경우도 있음을 지적하였다.

- 환경에 적응하는 것을 어려워하는 친구들은 검사 자체를 거 부해 버리고 아니면 이제 과제에 따라 반응 정도가 다른 아이 들은 집에서는 자기가 익숙한 상황에서 어느 정도 가져오거 나할 수 있지만 그림을 보고 뭐 아예 포인팅을 안 하려고 한다 거나. (S1)

- 동반 장애가 있으니까 언어 문제가... 요즘에는 시각장애 학교 에도 동반 장애가 있는 친구들이 많다고 하더라고요. 그 친구 


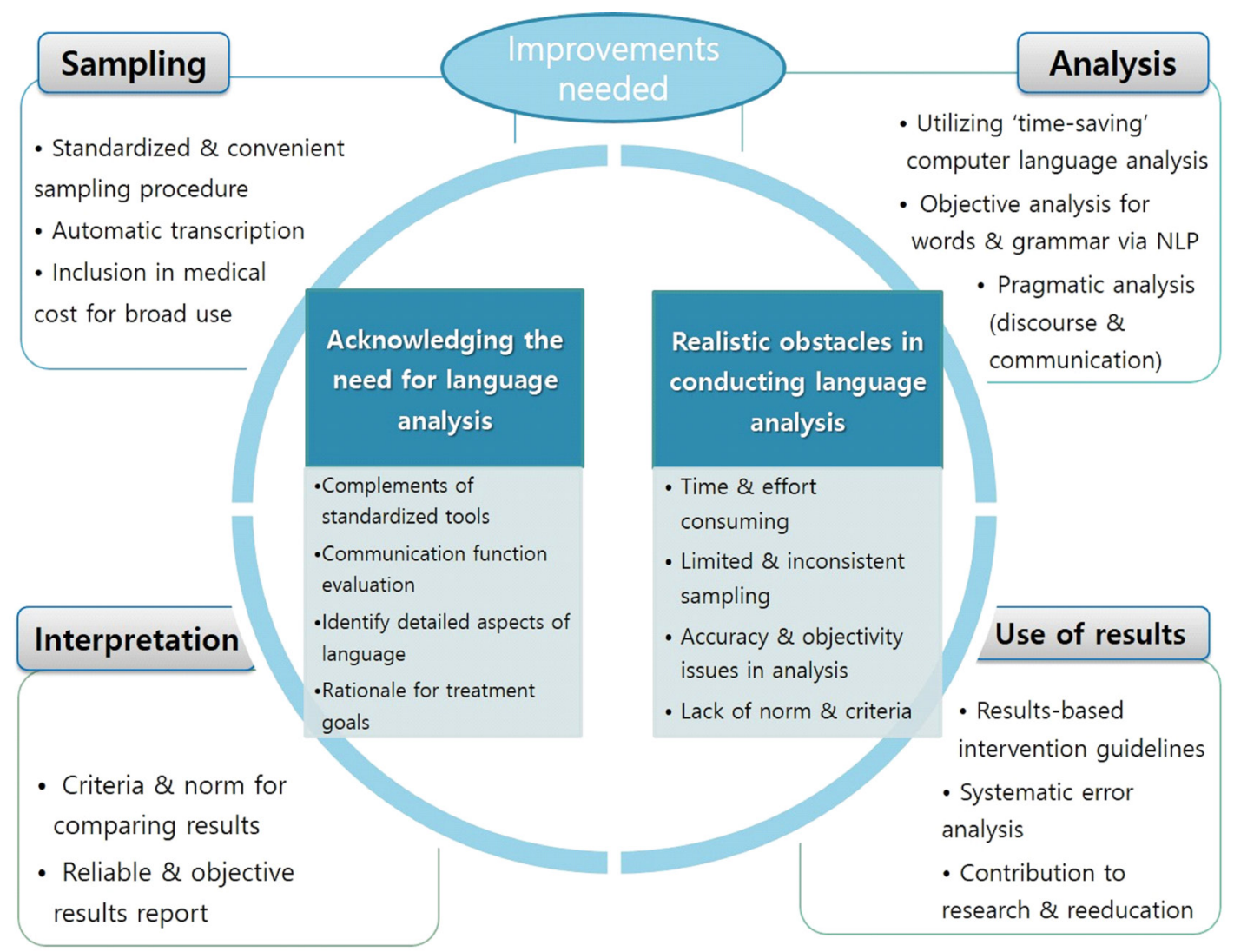

Figure 1. Themes \& concepts related to current status and alternatives of language analysis.

같은 경우에는 아예 전맹이었으니까 발화 분석을 할 수 밖에 없었어요. (S1)

- 우선은 요즘 아이들의 평균 또래 발달 수준이 (예전보다) 빠르 다는 느낌이 들거든요. 그 개월 수에 실제의 아이의 또래 수준 과 비교해봤을 때는 조금 차이가 나는데 어떤 부분에서는 안 심을 하시는 경우가 있고 하지만 안심하시기 보다는 조금 더 언어치료를 해야 하는데 결과만 보고는 '아 이제 언어치료를 안 해도 되겠다.' 그렇게 되면 조금 다시 한번 설명을 드리기가 지속적으로 치료를 해야 하는데 그 치료를 선택에서 빼시는 경우가 있으신 거 같아서. (S2)

- 단점은 그 검사 도구가 엄마들이 어디선가 평가를 언어평가 를 받아 왔는데 그 언어평가 검사 결과에 1 년 이내 이렇게만 나와도 정상으로 나오는데 사실은 보면 그 애는 분명히 정상 이 아닌데 어머님들은 다 언어평가 결과가 정상이라서 언어치 료를 받지 않아도 된다고 생각을 하거나. (중략) 숙련되지 않 은 치료사는 그냥 '앤 평가 결과가 이러니까 괜찮습니다.'라고 보는 거에요. (S3)

- 등가연령에서 6개월 미만으로 차이가 나는데 이게 그렇게 진
짜 크게 문제가 되지 않는 걸까 생각하는 거죠. (S4)

- 표준화검사를 하면 꼭 해야 하는 것들만 하면 되기 때문에 시 간을 오래 걸리지 않기도 하는데 업데이트가 너무 안되고 있 다는 단점이 있어서 그런 한계는 있는 거 같습니다. 표준화 등 가연령같은 것을 계산할 때, 이 정도가 과연 진짜차이가 없는 건가 생각하는 경우가 생기게 되는 거 같습니다. (S4)

- 예를 들어, PRES나 REVT 같은 경우에 어떤 문항이 있으면 ‘이거는 확실할까?' 싶은 것이 그림 같은 것도 옛날 거니까. 지 금 친구들은 모르는 것들이 있을 수 있으니까 예를 들어 뮈 컴 퓨터 이런 것이 있으면 지금 이런 컴퓨터는 아예 안 보이는 거 잖아요. 몰라도 모를 수 있으니까. (S5)

- PRES 검사에서 이제 발화 분석하는 부분이 정말 일부이잖아 요. 의미관계 하는 검사는 딱 하나밖에 없거든요. 그거 가지고 다 대변할 수 없으니깐 그래서 오히려 자발화 검사를 통해서 조금 더 의미관계 분석적인 측면에서는 그게 더 정확한 거 같 긴 해요. (S7)

특히 영유아의 경우 사용할 수 있는 검사도구가 부족한 현실이 
며 사용할 수 있는 검사도구가 있다 하더라고 아동의 컨디션이나 상황에 따라 검사가 어려운 경우가 많고, 부모 보고의 경우 과소/과 대 평가의 여지가 있음을 언급하였다.

- 영유아 수준에 머물러 있는 아이들 같은 경우에는 자발화 분 석을 조금 더 영유아 수준이라든지, 2세 전 수준 아이들한테 는 조금 더 자발화 분석에 비중을 더 두는 거 같고 그 이후의 아이들 경우에는 같이 이렇게 보완을 하는 거 같아요. 이제 영유아 수준의 아이들은 발화가 없이 비구어적인 행동이 많 이 나타나니깐 조금 더 관찰을 훨씬 더 많이 해야 할 거 같고 조금 더 발화 분석 비율이 많아져야 할 거 같아요. (S7)

\section{의사소통 기능 화용 평가 가능}

영역 별로는 특히 어휘나 문법보다는 의사소통기능의 경우 표준 화 검사로는 평가가 어렵다는 점을 언급하였다. 영유아 시기 아동 들의 경우 무발화 수준이나 초기 발화기 수준인 경우 문법보다는 기능이 중요하므로 발화 분석이 더욱 중요하다고 보았다. 학령전기 나 학령기 검사도구들도 화용이나 담화를 다루는 도구가 부족하 기 때문에 화용영역의 평가에서는 발화 분석을 좀더 비중 있게 사 용한다고보고하였다.

- 다른 동반 문제가 있다거나 아니면 아동이 어리거나 그런 경 우에는 실제 기능이 잘 반영되지 않는 경우도 있을 순 있어서. (중략) 표준화 검사에서 어... 잘 반영되지 못한 부분들, 특히 의사소통 기능 부분은 크게 알 수 없는 경우가 많으니까 그런 것들은 이제 기술을 해주고. (S1)

- 사실은 언어치료는 화용이 제일 중요한 건데 그 많은 평가도 구가 화용을 특히, 자폐 아이들의 부모님께서 가장 답답해하 시는 부분이 평가 결과는 좋게 나오는데 애는 늘 대화는 안 되 고, 사실 그게 어머님께 뭔가를 설명 드리려면 자발화 분석을 하던 대화 기능을 평가하던 그런 것이 사실은 중요 하잖아요. 그런데 그런 부분에 이제 한계가 있으니까 이제 뭐 기록이라 도 해서. (S3)

- 한 가지만 보기 때문에 다양한 측면을 보지 못한다는 점이 한 계점이지 않을까 생각합니다. 그러니깐 다양한 정말 화용이 나이런 부분에 대한 것들은 반영이 안되고 있어서. (S4)

- 일단 의사소통이 거의 없는 친구들도 가끔씩 보니깐요. 정말 백지장인 친구들이 오면 이 친구가 의사소통을 어떻게 사용 하고 있는지 행동을 분석 함으로써 확인을 하니깐 의사소통 행동 수단 이런걸 할 수 있어서 공식검사 보다는 이렇게 분석 하는 게 훨씬 더 좋다고 생각이 들구요. 그리고 또 큰 완전 초 등학교 입학한 친구는 공식검사로도 확인을 하지만 덩이말들
을 이제 확인해야 하고 담화적인 것도 확인해야 하니깐 꼭 필 요한 거 같아요. (S8)

언어능력의 구체적 양상 파악 가능

대체로 표준화 검사도구는 양적인 측정을 하기 위한 목적으로 실시하고 객관성 등 여러 이유로 더 비중 있게 실시되고 있음에도 아동 언어능력의 구체적이고 질적인 양상을 파악하는 데에는 한계 점이 있음도 언급하였다.

- 음... 표준화된 검사에서 보여주지 못하는 문제점이 드러날 수 도 있고 아동이 가진 강점이 드러날 수도 있고. (S1)

- 이 친구가 정확하게 학습 어휘가 부족한지 일상생활에 쓰는 어휘가 부족한지 사회생활에서 쓰는 어휘가 부족한지 그런 질적인 것들을 알 수 없고 볼 수는 없고 이 친구가 가지고 있 는 어휘의 양은 부족하다 이런거만 알 수 있으니 그런 것들은 조금 단점이지 않나 그래서 저희는 자발화 분석을 많이 하는 거 같아요. (중략) 그래서 이 어휘들은 잘 안 쓰더라 이 어휘는 잘 쓰더라 관용어구 같은 경우에는 우리가 확인을 할 수 없는 부분인데 구어를 사용하면서 관용어구는 잘 이해하더라 쓰 더라 이렇게 많이 볼수 있으니. (S8)

- 강약점을 잘 찾을 수 있는 거 같아요. 뭐가 부족한 거 같은데 잘 격리해서 잘 안 나오는 경우라든지 제가 확인을 못하는 경 우라든지 그런 경우들은 자발화 분석을 해보면 구문 부분이 라 던지 확인하면서 '아 이 친구는 이게 부족했구나' 라는 거 를 잘 확인해볼 수 있는 거 같고 저희는 큰 아이들이 많은 편 이니깐, 이야기라든지 담화 분석을 하는데 그러면 이야기 문 법도 이렇게 에피소드 하나에서 빠지는 건지, 아니면 전체 에 피소드에서 에피소드가 전체가 통으로 날아가는 건지 그런 것들을 잘확인할 수 있어서 좀 좋은 거 같아요. (S8)

\section{치료관련 의사결정의 근거}

전문가들은 공식검사도구들에 비해 발화 분석은 치료목표를 세 우거나 진전을 확인하는 근거로 적절하다고 평가하였다. 이는 시간 제약과 분석 어려움 등에도 발화 분석을 실시하는 주된 이유가 되 는 것으로 보고하였다.

- 어휘 같은 경우에는 그거를 바탕으로 어휘리스트를 만든다거 나 아이 연령에 맞게 한다거나 구문 같은 경우에도 잘 나타난 것도 있지만 안 나타난다거나 적은 횟수로 나타난다거나 하는 것들을 목표를 잡기도 하고. (S8)

- 아이들에 대해서 물론 뭐 K MB-CDI나 이런 것들이 보완적 으로 있기는 하지만 그게 설문으로 밖에 안 되는 영역이니까 
놀이 관찰이나 그때의 발화 이런 것들을 분석해서 기초선으 로 보는 것은 중요하더라고요. 그러나 사실 치료를 하려면 그 데이터 가지고는 그 아이에 대한 세밀한 반응들을 알 수 없으 니, 자발화 분석이나 행동 평가는 사실 하지 않으면 안 되는.

(S6)

- 저는 오히려 치료를 할 때 도움이 더 많이 된다고 생각을 하는 데 우선 평가는 아무래도 숫자로 보여주는 것이 누가 보기에 도 판단하기에 백분위 수가 얼마고 지금 어느 정도에 몇 살 수 준이고 이제 그런 것이 숫자로 나오는 것이 사람들이 이해하 기에 편해서 계속 쓰게 되는 거고, 근데 실제 똑같은 언어연령 이라도 애가 가진 문제와 재가 가진 문제의 양상이 다를 수 있 어서 그것을 반영하기에는 오히려 치료 상황에서는 더 도움 이 될 수 있을 것 같아요. (S1)

- 저는 일반화가 되는지 잘 확인할 수가 있는 거 같아요. 그니깐 치료 활동 안에서도 놀이 활동을 하면서도 많이 가르치는데 그게 이후에 저희와 있는 상황이라든지 다른 상황에서 확장 이 되었는지가 조금 확인이 되는 거 같아요. (S8)

- 아 물론 평가도 중요하지만, 치료도 매 회기 치료를 하면서 치 료가 다음 계획을 세우기 위한 평가도구도 될 수 있는데. (중 략) 매번 공식적인 검사를 평가를 할 수 있는 부분이 아니기 때문에. 좀 학령기 아이들한테는 자발화 분석이 좀 더 된다면 다음 치료를 목표를 세우거나 할 때는 여러 가지로 도움이 될 거 같아요.(S2)

- 이제 그게 지금 기본적으로 그냥 말을 할 땐 되지만 그림을 보 고 설명을 할 땐 못하고 이러면 그걸 또 이제 전사를 해놨다가 또 애가 뮈라고 말을 했는지 전사를 해놨다가 어머니께 다시 설명을 드려야 되고, 그러니까 내가 이걸 왜 수업에 치료 목표 로 해야 하는지 사실 어머님께 설명을 드릴려면 뭐가 확실하 게 제시가 돼야 하는데 그게 근거가 없으면 어머님은 '왜 선생 님은 이렇게 쉬운 것을 시키지 애한테?’ 사실 그러거든요. (S3)

- 발화 분석은 치료를 목적으로 할 때 좀 더 많이 했던 걸로 생 각이 되는데요. (중략) 없는 의사소통의도의 목표를 세워서 치료 목표로 활용하는 거 같습니다. (S4)

- 진전도가 느려도 자라고는 있잖아요. 근데 치료사든 부모든 지치기 쉬울 수 있는데 느린 속도지만 자라고 있는 준거가 표 준화 보다는. 거기에서는 잡히니 그래서 그런 것들을 꼭 활용 해 보자라고 하는데 이렇게 2세 6개월 미만인 경우에는 선생 님들이 자발적으로 많이 쓰더라고요. 진전도 이걸로는 안 나 오니까. (S6)

- 어떤 애는 제가 지금 치료하고 있는 애는 어릴 때 치료실에 다
녔는데 병원도 가봤는데 심지어 언어재활사가 애 언어 필요 없다고 해서 몇 년을 치료 안 받고 있다가 오셨어요. 근데 자폐 에다가 대화 주고받는 것이 유지가 안 되는데 그러니까 평가 결과 상으로는 괜찮은 거죠. 인지가 되니까. 개념적인 것은 이 제 다 패스되니까. 그래가지고 엄마가 자기는 치료를 빨리 받 고 싶었는데 안 받아도 된다고 해서 안 받았다고 애기하시는 분들도 몇 분 계세요. (S3)

\section{발화 분석 실시의 현실적 어려움}

많은 시간과노력이 필요

대부분의 전문가들은 표준화 검사에 많이 의존하고 있다고 보 고하면서도 발화 분석의 필요성은 전반적으로 인정하였다. 그러나 실제로는 발화 분석을 많이 실시하지 못하고 있음을 보고하였다. 이는 여러 이유가 있지만 가장 많이 언급한 이유는 발화 분석에 많 은 시간과 노력이 필요하다는 것이었다. 발화 수집뿐 아니라 분석 에 시간이 많이 소요되는데 이러한 발화 분석 시간은 치료나 평가 시간에 반영이 되지 않고 근무가 끝난 후나 치료 사이의 빈 시간을 이용해야 하는 상황이었다.

- 시간이나 경제적인 이유. 시간적인 이유로 발화 분석을 하기 는 아무래도 어려우니까. 발화를 전사를 해서 분석을 하고 하 는 일이 상당히 시간이 많이 소요가 돼서. (S1)

- 음 대부분 임상에서 근무하시는 선생님들이 그렇듯이 계속 치료를 하는 중간 중간 평가가 들어가게 되고 그러면 그 평가 때문에 다른 일들을 계속 미룰 수 없는 거고 뭐 어쨌든 제한 된 시간에서 빨리 결과가 나와야 되는 거고 그러다 보니 자발 화 분석을 위해서 시간을 빼놓을 수도 없고 음 그게 제일 큰 문제죠. 약간 시간을 내야 추가로 시간을 더 내야하고 조금 더 집중을 해서 해야 하기 때문에 그게 그 순간 그 치료하고 끝나 고 그 안에서 다 이루어질 수 있는 게 아니여서 조금 더 추가 시간이 필요한 경우가 있어서 그리고 번거로움. (S2)

- 지금은 치료 끝나고 비는 시간이 있거나 그럴 때. (S2)

- 그걸 나중에 분석하려면 너무 시간이 너무 오래 걸리고 머리 가 빠질 것 같은 너무 힘들어요. (S3)

- 수업 때 내가 느끼기에 ‘애가 지금 이런 거야’라고 생각을 하면 그걸로 딱 이해해서 끝나는 거지 그것을 막 나중에 따로 타이 핑하고 그러기에는 사실 치료도 좀 많기도 하고요. 그렇게 해야 하는 것이 맞다고 생각은 하나 그렇게 하기에는 실제로 너무 시 간과 노력이 그리고 또 정해진 시간이 있는데 한 애만 노력을 기울여 줄 수도 없고, 해주려면 전부 해 줘야 하는데 그렇게 누 구는 해주고 누구는 안 해주고 할 순 없어서 그렇긴 하죠. (S3) 
- 시간이 너무 오래 걸려서 전사도 하고 분석도 하는데 제때 보 고서를 낼 수 없을 거 같아서. 결과를 들으러 오는 날짜까지는 써야하니깐. (S4)

- 보고서 쓰고 분석하는데 사실은 업무 시간 이외에 많은 시간 을 할애했던 거 같아요. 치료가 끝나고 나면 특히 보고서 쓰는 저희는 항상 조금 더 근무를 하다가 퇴근하고 그랬던 거 같아 요. (S7)

\section{제한적, 임의적 표집}

연구에 참여한 전문가들은 대체로 발화 수집을 하고 있다고 언 급하면서도 본격적인 발화 수집 절차를 거치기 보다는 표집 상황 이나 기록 방법, 샘플 크기, 대화 상대자에 있어서 매우 임의적이고 제한적인 절차를 사용하고 있다고 언급하였다. 앞서 언급한대로 발 화 분석을 위한 시간을 낼 여건이 부족하다 보니 본격적으로 발화 를 충분히 수집, 분석하기 보다는 제한된 치료나 평가 시간 내에서 아동의 발화를 제한적으로 수집하여 분석하거나 아예 수집과 분 석의 과정을 거치치 않고 아동의 말을 듣고 바로 주관적 인상에 의 존하여 분석하고 있다고 언급하기도 하였다.

- 자발화 분석을 어.... 그걸 가지고 뭐 진짜로 MLU를 점수로 산 출 하기 보다는 현재 주로 사용하는 의사소통 길이가 뭐 한 낱 말이다 아니면 최장 두 낱말 까지는 나오나? 뭐 주로 발성과 제스쳐를 사용한다든지 그냥 정확한 빈도를 카운트해서 세 는 것은 아니고 사실은 그때 봤던 인상으로. (S1)

- 수업할 때 다 적어요. 그러니까 애가 내가 생각하지 못했던 표 현을 한다거나 늘 일상적으로 사용하는 것들은 알잖아요. 애 가 늘 하던 말인데 오늘은 길고 완전한 문장으로 애기했다거 나 평소에 쓰지 않는 의미관계를 썼다거나 그러면 바로 기록 을 해요. (S3)

- 사실 뭐 기본적으로 절이나 구나 애가 뭐 어떤 구를 제대로 쓴 다거나 어떤 절을 제대로 쓴다거나 이렇게는 하지만 그리고 기 본적인 의미관계를. (중략) 기본적으로 보기는 하지만 막 그렇 게 분석을. 애기를 나누다가 어떤 부분이 부족하다 하면 가르 치게 되는 거지 막 그렇게까지 할 시간은 뭐 없어요. (S3)

- 뭐 애가 어느 정도 썼다. 이렇게 딱 봐서 보는 편인데, 나눠서 뭐 형태소 이렇게 나눠서 보지는 않고. (중략) 저는 길이도 보 기도 보는데, 그렇게 $\mathrm{MLU}$ 따져서는 잘 안 하는데 길이도 같 이 그냥딱 보고. (S5)

- 실제로 할 때 사실, 많이 데이터로 하지 않았고 거의 10 발화로 해서 더 길게 안 하게 되는 이유가 아까도 말했지만 반복? 횟 수 세고 이러는 게 너무. 10 문장 정도는 이렇게 몇 분의 몇 이
게 바로 나오니까. 대표되는 뭐 이렇게 10 발화 정도만 해도 아 이의 현재 수준 이런 것이 가늠이 되어서. (S6)

- 학령기 아이들은구문 분석을 할 때 LSSC를쓰면서 했고다 따로 그아이들의자발화를 수집해서 분석하지는 않았거든요.(S7)

아동의 발화를 기록하는 방법도 대부분 조음이나 유창성 등의 말문제를 동반하는 경우에나 진전 평가를 위한 경우에만 녹화나 녹음을 하고 그렇지 않은 경우 바로 듣고 전사하는 방법을 사용한 다고보고하였다.

- 원칙적으로 하려면 비디오 테이핑이나 녹음도 하고 그거를 다 시 하면 좋겠지만 실제로 임상에서 그것을 매 아동마다 사용 하기는 현실적으로 어렵고 그래서 어... 특징적으로 들리는 말 들을 그때 그때 평가하면서 적어놓고. (S1)

- 보통 발화가 짧은 아이들의 경우에는 거의 실시간으로 적고, 왜냐하면 녹음이나 녹화는 부모의 동의가 있어야 하는데 치 료 처음부터 동의를 구할 수 없기 때문에 그 때는 그냥 기록하 고요. (S2)

- 발화 분석을 녹음이나 녹화해서 보지는 않고요. 녹음이나 녹 화는 유창성장애 평가할 때 정도고, 아이들의 발화 분석은 녹 화나 녹음을 활용하지 않는데 수기로. (S4)

- 조음이 있는 친구들은 거의 다 녹음하는 편이고, 아니면 저는 전사하는 편이에요. 전사할 내용이 많으면 녹음하는 편이고, 그 정도의 아동은 많이 없어서 하면서 다 적는 편이에요. (S5)

- 거의 실시간으로 치료 중일 때는 바로 적었고, 사전 사후 평가 를 좀 해야할 때는 녹화를 해놨던 자료를 가지고 하고. 그러려 고 노력을 했는데요. 물론 상황이 늘 다른 거라 자발화 분석 만을 위한 영상은 아니고. (S6)

발화 수집 상황도 가정이나 양육자와의 상호작용, 혹은 아동의 행동 관찰로 목록표 작성하기 등으로 다양했으며, 대화 상대방도 평가자, 양육자, 또래 등으로 다양했다.

- 발화의 대표성을 가지려면 사실은 환경적으로도 고려를 해야 하니까 낮선 환경에서보다는 친숙한 환경에서 샘플을 따는 것 이 좋겠죠. 집에서 어떻게 하는지 보여주세요 그러면 녹화는 잘 됐으나 발화는 잘 들리지 않고, 막 아이 얼굴만 나오게 찍어 서 어떤 상황인지도 모르겠고. 계속 뭔갈 가르쳐 주시고. 그리 고 이제 뭔갈 보여줘야 한다고 그러시는 건지 본인이 계속 지 시하시고 어떤 면에서 더 부자연스러워 보일 수도 있고. (S1)

- 주로 보는 게 아동 발달 아동 언어발달, 아이가 표현을 하고 있는지 잘 따라가고 있는지를 저는 상호 또래와 놀잇감을 가 
지고 상호작용하면서 그리고 어머니와 짧지만 어머니와 상호 작용하는 부분을 보고 말씀을 드리고 있습니다. (S2)

- 어떤 의도가 몇 가지 정도 나오는지 이게 있는지 없는지 의도 목록표를 놓고 있는지 없는지 체크하거나. (S4)

분석의 정확성과 객관성 문제

발화를 수집한 후 분석하는 과정에서도 전문가들은 본인들의 분석이 정확한지에 대한 확신을 갖지 못하고 있었고, 이를 동료와 의 의사소통이나 관련 자료 찾아보기 등으로 보완하고 있으나 그 러한 과정에서도 명확하게 해결한다기 보다는 기준이나 지침에 대 해 지속적으로 의문을 갖게 되는 경우가 많다고 보고하였다.

- 특별히 그런 것은 없고요. 현재 발화 분석 기준에 '미완성 문 장은 포함하지 않고 한다.'라고 되어 있는 그 기준이 무엇을 위 해서 그 문장을 포함하지 않기로 한 것인지가 사실 평소에 조 금 의아했고, 치료를 위한 상황, 아동을 평가할 때는 미완성 문장도 나름 가치가 있고 좋다고 생각을 하는데. (S6)

- 제가 하고 있는 게 잘 맞나? 맞는건가? 정확한가? 그런 느낌. 하면서도 항상 제 거에 대해서는 이게 내가 이 아이의 발화를 정확하게 분석한 게 맞나라는. (중략) 동료 치료사와의 의사 소통이 굉장히 저한테 필요한 거 같아요. (중략) 결과를 다 써 서 보고서 한 장에 이 아이의 의사소통능력을 잘 반영했나라 는 의문점? 그래서 그럴 때는 저 같은 경우에는 센터에 있는 다른 치료사분께 이제 뮈 확인? 아니면 의견. (S2)

- 예전에 대학원 다닐 때 발화 분석 수업시간에 수업 때 하기는 했지만 하면서도 계속 교수님께 뮈 다 자기가 발화 분석 해온 것을 뭐 확인을 받는 차원에서 뭐는 뭐가 교수님께서 그거는 뭐다 이랬는데 사실 그게 딱 떨어지지 않게 되게 어렵고 애매 한부분이 많아요. (S3)

- 교수자의 기준이랑 학생들의 기준이 다른 거죠. 그래서 항상 보면 평가를 다하고 나서도 교수자가 평가를 하는 그 상황에 서 있어야 되는 게 맞고요 하고 나서도 같이 논의해서 기준을 이렇게 합치 일치를 이루어야 하는 시간적인 요소를 더 많이 소요가 되는 거 같아요. (S7)

- 아니면 물어봐요. '선배는 어떻게 떼요? 나는 이렇게 생각하는 데 제가 틀린 거에요?' 이렇게 이 선생님 말과 저 선생님 말이 또 다른 경우들이 기준이 또 다같이 배웠는데. (S8)

구체적으로 의미, 문법 등 특정 영역의 분석 방법에 대하여 기준 이 애매하여 정확한 분석이 어렵다고 특정하여 언급하기도 하였다.

- 그게 저는 제일 어렵더라고요. 사실은 형태소랑 단어랑 구별
하고 이게 저는 제일 어려워서 사실은 그런 거 제일 많이 물어 보는 거 같아요. 기준이 이제 생기면 좀 좋을 거 같아요. (S8)

- TTR 할 때, 같은 낱말 세는 거 할 때 포함되는 문장, 뭐 이런 것들이 아동에 따라서 약간 또 다른 느낌으로 와 닿을 때가 있어서. 예를 들면, 애가 놀면서 '에디가, 에디는, 에디가 있어' 이렇게 했을 때 앞에 두 개를 버려야 되는지, 버리긴 또 아깝 고, '애가 저런 조사도 쓰는데' 이런 것을 남겨두고 싶은데 그 런 것들. (S6)

- 특히 학생들이 틀리죠. 특히 이제 의미관계 그 자체를 정확하 게 특히 대상이라든지 실체라든지 이런 것들을 되게 헷갈려 하거든요. 근데 저도 헷갈리는 경우가 상당히 많아요. (S7)

- 어쨌든 좀 낮은 수준의 아이들일 때 그것들을 사실 하나하나 그 아이의 발화를 수집해서 이렇게 치료 수준을 정할 수밖에 없을 것 같은데 음성 언어를 어디까지 넣고, 빼고. (S6)

- 저 이야기 분석할 때도 많이 혼동스럽고 이게 결속표지로 들 어가야 할까 이런 것들을 다 책으로 다 찾아봤었는데. (S8)

\section{결과 해석을 위한 규준 부재}

발화 수집과 분석 과정에서 어렵게 시간과 노력을 들여 발화를 수집해 분석을 마치고 나서도 그 결과 해석과 활용에 있어서도 문 제점이 있음을 지적하였다. 가장 큰 문제는 분석한 결과를 비교 하 여 언급할 기준이 없거나 모호하다는 것이었다. 또, 발화가 제한적 으로 표집되다보니 발화 분석 결과가 주관적인 인상 언급에 그치거 나 아동이 보인 의사소통행동을 기술하는 수준에 그치는 경우가 많다고 보고하였다. 힘든 분석 과정에 비해 최종적 결과가 빈약하 거나 만족스럽지 못하다는 생각을 하고 있었고 이러한 생각이 다시 발화 수집과 분석이 더 폭넓게 이루어지지 못하는 요인으로 작용 하는 악순환이 나타나고 있었다.

- 네. 발화 빈도를 몇 분에 몇 개다 이렇게까지 하지는 않지만, 검사를 하는 상황에서 발화 빈도가 매우 낮았다든지 그런데 그거는 어떤 기준을 가지고 하는 것이 아니라 인상이죠. 내 인 상으로 너무 적다든지 뭐 발화 빈도는 낮지 않으나 뭐 특정 발 화를 계속 반복한다든지. (S1)

- 발화 분석 같은 경우에는 사실 특별한 경우가 아니면 보고서 에 밑에 몇 줄로 막 다른 항목으로 정해서 쓴다기 보다는 표현 언어를 기술하면서 자발화를 봤더니 뮈 이런 특징들을 보이 더라 정도로 기술을 해서. (S1)

- 우선은 가장 바로는 부모 아이 부모에게 이러이러한 상황이었 고 이러한 반응을 보였고 해서 부모 상담을 할 때 사용을 하고 요. 그 다음에는 보고서 기록을 하고요. (S2) 
- 보통 선생님들이 라포 형성이라는 이름으로 1,2 회기 안에 그 런 것들이 하는데 그때 행동 기준의 준거? 이런 것들을 좀 있 으면 좋은 것 같더라고요. (S5)

특히, 학령기 아동의 경우 발화 분석에 대한 비교 기준이나 연구 가 매우 부족한 상황이어서 학령전기 아동 발화 분석에 비해 더욱 더 해석에 어려움을 겪고 있는 것으로 나타났다.

- 근데 실제로 고 또래 아이들이 발화가 취학 전과 초등 일학년 을 지나면서 차이가 확 나거든요. 그것들을 조금 그런 규준이 있으면 지금 초등 입학을 나두고 유예를 하냐안 하냐 그거를 고민하는 부모님들에게는 구체적인 도움을 드릴 수 있을 거 같아요. 아이가 일 년 동안 이 정도 속도로 발달을 하면 일 년 동안 발달 속도를 잘 따라잡고 아이가 또래와 같이 잘 초등학 교 입학해서 생활을 할거다라고 생각하시는데, 실제적으로 초등학교 일학년 그 규준이 현재는 정확히 없으니깐 그냥 추 정치이거나차이가 정확하게 실제적으로 다가오지는 않는 거 같거든요. 그 규준이 딱 있을 때 부모님과 상담을 할 때는 실 질적으로 구체적으로 어떤 부분에 있어서 도움을 주면 좋을 지가 나올 거 같아서. (S2)

또, 학령전기 아동의 경우에는 구문 영역의 평균발화길이(MLU) 등에서 결과를 비교할 연구들이 있었으나 이러한 연구들도 너무 오래된 것이고 대규모 전국적 샘플에서의 결과가 아니기 때문에 비 교하면서도 현재의 아이들 수준을 잘 반영한 것인지 의문을 제기 하기도 하였다.

- 특히 규준 같은 경우에는 사실은 김영태 교수님 규준밖에 없 잖아요. 사실은 그게 10 년도 넘은 규준인데. 그래도 좀 검증된 게 그거기 때문에 그거랑 비교를 하긴 하죠. 그때는 사실 기준 이 없었기 때문에 저희들이 책에서 배운 대로 보통 만 1 세 정 도 되면 MLU가 1-2사이 이런 식으로 어느 정도 예측치가 있 잖아요. 그런걸 가지고 예측을 했던 거 같고 비교를 한다면 그 랬던 거 같고 주로 언어발달의 지연이 있는 아이들이었기 때 문에 저희들이 예측하는 것보다는 훨씬 못 미치죠. 그 아이들 이 보이는 현재의 보이는 상태 현재의 능력을 확인하는 차원 에서 사용했던 거 같구요. (S7)

\section{발화 분석에 대한 개선 요구 샘플링}

표준화되고 편리한 표집 절차

연구에 참여한 전문가들은 발화 수집의 어려움의 하나로 상황
과 수집하는 발화의 양, 대화 상대방, 기록 방법 등에 대해 각자 매 우 다른 방법을 사용하고 있음을 보고하였다. 이러한 표준화되지 못한 표집 절차는 이후 결과 해석과 활용에도 제약을 주어 전반적 으로 발화 분석을 어렵게 만드는 요인으로 언급되었다. 이에 대한 대안으로는 발화 수집 상황이나 교구 등을 표준화할 필요성이나 발화 분석의 표준화된 절차, 프로그램의 개발에 대하여 언급하였 다. 또한 연령이나 장애 별로 주요 관심되는 영역이나 문제에 따라 분석 내용, 측정치들이 다를 수 있으므로 이를 고려하여 발화 표집 이나 상황을 체계적으로 조정, 적용할 수 있는 지침이 필요함을 언 급하기도 하였다.

- 아무래도 공식검사보다는 제가 할애 해야 하는 시간이 많고, 그 많은 거에 비해서 제가 한 것은 표준화되지 않았으니까 제 가 틀릴 수도 있고. (S5)

- 어 프로그램이 있으면 기록해서 분석돼서 나오면 엄청 많은 분들이 쓰시지 않을까. 표준화되게 되어있다면. (S5)

- 어떤 상황에서 말한 것이냐 이런 것이 변수일 수도 있겠다라 는 생각이 드네요. (중략) 무엇 무엇을 제시하고. (S7)

- 장애군에 따라서 생각을 해보면 자폐 아이들은 아무래도 의 사소통기능을 잘 쓰고 있는지 그 다음에 그거를 어떤 수단으 로 사용하고 있는지 그 수단이 얼마나 다양한지 그거를 확인 하고 그거를 조금 더 중점적으로 보고 있는 거 같고요. 지적장 애 아동 같은 경우에는 느리니깐 이 친구는 구문을 어디까지 사용하였는지 복문을 시작하였는지 안긴문장은 시작하였는 지 그 다음에 오류는 많이 있는지 문법형태소 오류는 많이 있 는지 확인을 하는 거 같아요. (S8)

- 자폐 아이들의 부모님께서 가장 답답해하시는 부분이 평가 결과는 좋게 나오는데 애는 늘 대화는 안 되고, 사실 그게 어 머님께 뭔가를 설명드리려면 자발화 분석을 하던 대화 기능 을 평가하던 그런 것이 사실을 중요 하잖아요. (중략) 뇌병변 장애 애들도 발화가 되는 아이들 같은 경우에는 어른들 손에 많이 이끌려 다니다 보니까 낯 병동에 가니까 어른들이 하는 표현에만 익숙해져 있어서 또 아이들이 애기하는 것은 잘 그 러니까 너무 어른스럽게 이야길 하니까 어른들은 애가 말을 잘하고 의젓하다고 이야길 하지만 막상 또래에서 사용하는 표현들은 모르는 경우도 있고. (S3)

덧붙여 표준화된 절차대로 발화 수집을 실시할 수 있게 하는 프 로그램을 PC나 핸드폰이나 앱을 연계한다면 편리하게 실시하고 언 제 어디서든 발화수집이 가능해 좋을 것 같다는 의견도 있었다.

- 치료실 밖에서 아이들의 반응들을 기록한다거나 특정 상황 
에서는 아이가 발화가 없는 집에서는 다 표현할 수 있다라고 하시는 분들도 계시거든요. 그것들을 "노는 거 찍어서 보내 주 세요.' 라는 정도인데 그런 프로그램이 있으면 한번 해서 그걸 로 활용을. (S2)

- 근데 컴퓨터로 이런 게 되면 편리할거라고 생각하지만 오히려 복잡해지면 더 다가가기 귀찮은? 사용하기 어려우면 AAC처 럼요. 그림을 붙이지 컴퓨터를 켜서 사용하게 되지는 않더라 고요. 예상보다 복잡하다 싶으면. AAC처럼 핸드폰으로도 사 용하게 할수 있으면. (S3)

\section{자동전사}

발화 분석에서 단순한 작업이지만 가장 시간이 소요되는 것으 로 언급된 것이 전사 과정이었는데 일부 전문가들은 최근 스마트폰 의 음성인식 등의 기술이 널리 보급되어 있는 것을 감안하면 컴퓨 터를 이용하여 발화를 전사할 수 있다면 언어 분석 과정에 드는 노 력을 경감하는데 큰 도움이 될 것으로 언급하였다.

- 뭐 만약에 치료사의 질문에 대해서 뭐라고 했는지 반응 같은 것에 대해서 컴퓨터가 알아서 이렇게 나눠서 해줄 수 있으면 따로 기록을 안 해도 돼서 최고인데. (S3)

- 이렇게 저희가 카톡 음성으로 하면 애가 적어주잖아요. 그런 거면 너무 좋겠다. 그러면 아까 어려운 점의 고충이 전사를 하 는 것이 영상을 보면서 전사를 하는 것이 시간적인. (S6)

- (이전에 사용해본 컴퓨터화된 언어 분석 프로그램이) 전사에 너무 많은 시간이 든다? 그러니까 그거 포함. 내가 분석을 해 야 하는 거잖아요. 저희가 녹음이나 녹화만 하면 전사부터 해 주면 좋겠네요. (S8)

- 제가 우리말로 이야기를 했을 때 인식률이 상당히 좋은 편이 에요. 그리고 기록도 되고 저장도 되니깐. 그렇게 하면 그렇게 해서 인식률이 깨 좋다라고 느껴서, 이렇게 인식률이 좋으면 발화하는 거 전사하는 것도 좋을 거 같다라는 생각을 했는데.

- 근데 이게 될지 모르겠는데 핸드폰에 말을 하면 그게 적히잖 아요. 이거 음성이 텍스트가 되는 거랑 음성 파일을 그대로 넣 으면 컴퓨터 자체에서 문자로 변환을 하겠죠. 그거를 가지고 분석을 하는 거. (S7)

- 시간을 들여서 전사하지 않아도 되니깐 해 볼 수 있지 않을까 생각합니다. (S4)

그러면서도 언어치료 대상이나 평가 대상자의 말은 조음 오류가 있을 수 있고, 어린 아동의 경우 불분명한 말이 많을 수 있으며, 대
상자의 말과 상대방 발화와의 구별, 사투리 및 비문 처리 등의 문제 때문에 일단 자동 전사가 가능한 방법이 있으면 일차적인 자동 전 사를 거친 후에 평가자가 재확인 할 수 있도록 하는 것이 바람직하 다고 생각했다.

- 그게 왜 요즘은 사운드 텍스트? 그런 프로그램들 있으니까 그 걸 돌려서 만약에 그리고 그게 잘 됐는지 아이들 같은 경우 소 리가 웅얼거리고 조음 오류가 있어서 컴퓨터가 잘못 전사한 부분만 체크하고음. 그거는 할 수 있을 것 같은데요? (S1)

- 전사만 해놓으면 그 다음에는 뭐 약간 우려되는 부분은 아까 아이들이 웅얼거린 부분 그리고 이제 조음 오류 때문에 개가 틀리게 발음했는데 그것을 컴퓨터는 또 다른 단어로 오해해 서 잘못 번역을 한다든지. $(\mathrm{S} 1)$

- 만약에 녹음한 것만 가지고 입력을 하면 전사를 해주고 거기 에 사람이 어느 정도 보완만 해주는 프로그램이라면 그래도 꽤 실용성이 있을 것 같은데요? (S1)

- 근데 여전히 한계가 있지요. 왜냐하면 여기는 자동으로 구 의 미 인식이 돼서 그거로 변화되기도 하더라고요. 문맥상, 근데 그렇게 해서는 안되기 때문에, 그래서 정말 그 소리 그대로 해 야 하는데. 그대로 안되기 때문에 그런 부분이 다 약간 뭔가 통제될 수 있으면, 온전히 그 소리를 그대로 녹음해서 할 수 있 는 시스템이 있다면 정말. (S2)

- 사실 아동의 발화들은 그 목소리로 전사돼서 텍스트로 전환 돼서 딱 되어있을 때는 알기 힘든 부분이 많기 때문에 그 부분 은 사실은 영상과 같이 보면서 아이들의 행동이나 제스처 부 분이 많이 있어서 그 부분을 전부 담기 어려울 거 같고. (S2)

- 구분을 해서 아동 목소리인지 치료사 목소리인지 분석도 해 주고 그 다음에 그럴 때 아이들이 반복하는 거라든지 묶어서 필요 없는 발화는 빼주고 그 다음에 분석을 개네가 해주면 좋 을 거 같은데요. (S8)

- 전사할 때 정확하지 않은 소리를 애가 얼마만큼 잘 전사를 할 것인지 그 상황에 있다면 뭐 가방을 다방이라고 했어도 '아 가 방을 다방으로 잘못 말한 거구나. 알 수도 있지만 그냥 음. 그 냥 녹음한 샘플만 컴퓨터가 전사를 하게 되면 어... 그거는 이 제 프로그램을 어떤 프로그램을 사용하느냐에 따라 다르겠지 만 예를 들어, 애가 그 뒷말도 다르게 예측을 해서 웅얼거리는 소리를 자기가 예측한 다른 소리로 전사를 해버린다든지. (S1)

- 이거랑 분석할 때, 그 사투리 같은 거 할머님들이 애기하시는 거랑 표준어랑 다른 거 있잖아요. 예를 들어 '계란'인데 '겨란' 이라고 한다던가 그게 뭐 틀리게 될 수도 있을 것 같아서. (S5) 
수가 반영으로 실시 확대

발화 분석이 매우 시간과 노력이 많이 드는 일임에도 이에 상당 하는 평가비가 반영되지 않았다. 특히 항목 별로 평가비가 책정되 는 병원 세팅에서 일하는 전문가일수록 발화 분석의 수가 반영에 대하여 언급하였다. 발화분석에 들이는 과외의 시간과 노력이 반영 되려면 발화분석의 수가 포함 및 현실화가 필요함을 언급하였다.

- 많이 비싸져야 되는데 어머니들 입장에서는 선생님이랑 잠깐 뭐 한 30 분 놀았는데 돈 많이 내라고 그러면 음.. 그리고 공식 검사는 이거에 몇 점 이렇게 뭔가 체계적이고 과학적인 것 같 은데 이거는 뭐라고 뭐라고 거기에 MLU라고 쓸 수 있는데 엄 마들은 그래서 이게 몇 살이라는 거냐 그게 중요하니까. 그리 고 의사들도 그게 중요하니까. (S1)

- 충분한 시간과 여건이 되면 하면 좋으나.. 그런데 우리가 평가 비를 얼마로 측정할 것이냐에 사실 그 내가 들이는 시간과 그 게 다 포함이 되려면. (S1)

\section{분석}

컴퓨터 언어분석 시스템으로 시간, 노력 절감

전문가들이 가장 많이 언급한 발화 분석의 어려움은 시간과 노 력 집약적인 일이라는 점이었다. 그 대안 중 하나로 언급된 것이 컴 퓨터 언어분석이었다. 이는 과거 언어치료학계에서 개발, 보급되었 던 언어분석 소프트웨어를 사용해본 경험이 있는 전문가들이 있었 고, 자연어처리기술에 기반한 형태소 분석기나 프로그램을 알고 있 는 경우가 많았기 때문이다. 기존 컴퓨터 언어분석 프로그램이 출 시된 것은 꽤 오래 전이었는데 사용 경험이 있는 전문가들은 이 프 로그램들이 매우 편리하다기 보다는 수기로 분석하는 것에 비해 시간과 노력에 큰 차이가 없었다고 보고하였다. 때문에 전문가들은 이에 대해 최근 더 발전된 언어분석 기술들을 반영하여 좀더 객관 적이고 편리하게 분석을 할 수 있으면 하는 기대를 드러냈다. 하지 만 자연어처리기술에 대하여 그리 많은 지식이 있는 것은 아니어서 그런 기술을 이용할 수 있으면 좋겠다거나 어디까지 실현 가능한지 모르겠으나 자동적인 분석이 가능할 것으로 예상하는 경향을 보 였다.

- 예전에 그 뮈였죠? 그것을 좀 써보려고 했었는데 결국에는 자 발화를 손으로 다 따야하고 뭐 카운트해서 거기에다 넣으면 평균 정도만 구해주는 거여서. 계산만 해주는 거여서 그렇게 편리해지지는 않았어요. 어차피 해야 할 것은 다하고 거기서 해주는 계산들은 뭐 나도 뭐 그냥 계산기를 사용해도 그렇게 시간이 많이 걸리는 부분은 아니니까. (S1)

- 자동으로 나눠주고 분석까지 해주면 뮈. (S5)
- 조음에도 보면 음성을 분석해주는 것이 나왔는데. (중략) 근 데 국제음성기호대로만 하면 개가 음운변동 뮈 자음정확도? 뮈 이런 것이 도표로 해서 다 나오거든요? (S6)

- 그건 분석을 내가 해야 하는 건데 사실 컴퓨터가 보조를 조금 도와줘야 되는 거라고 그래야 자동화가 아닌가? 어쨌든 만약 에 애가 음성을 넣어서 애가 처리해서 가는 것이 완벽해지면 모르겠는데 사람 손을 거치게 해야 한다면 뭐 예를 들어서 내 가 봤을 때 이거는 형용사고, 이거는 체언이고 뭐 어미고 이러 는 것들은 컴퓨터화가 아니거든요. (S6)

- 일단 불편한 게 줄어들 거잖아요. 그래서 저희가 시간이 많이 들고 하는데 그런 부분이 줄어들 거 같고. (S8)

- MLU 계산하거나 TTR 계산할 때 귀찮으니깐 여기 낱말만 딱 딱 넣으면 마지막에 계산이 되도록. 발화 수랑 낱말이라든지 그런 거. (S8)

- 거기서 해주었으면 하는 거는 형태소 분석해서 발화 길이를 확인해주는 거 이런 것들을 다 해주는 게 좋은 거 같은데 머 릿속에서는 그렇게 생각을 했는데 그러기에는 너무 얼토당토 하지 않나. (S8)

- 일단 시간이 확실히 절약되니까. 사실 치는 것은 금방인데 분 석하는 것이 힘들잖아요? (S5)

- (사용해본 언어분석 프로그램이) 진짜 너무 대단하다. 그 하 나를 똑같은 것을 분석할 때 저희는 되게 오래 걸렸는데 딱치 면은 바로 제가 분석한 것이 똑같이 나오니까. 그때 이미지가 그냥 빠르다. (S5)

- 일단 (컴퓨터로) 하게 되면, 근데 많은 선생님들이 못 하시는 것이 시간이 많이 걸려서 못 하시는 것 같은데, 시간 절약이 많이 돼서 쓸 것 같기도 하고 나오게 되면 신뢰도가 이미 되어 있는 거니까쓸 것 같아요. (S5)

자연어 처리기술 $(N L P)$ 을 활용한 어휘, 문법의 객관적 분석

전문가들은 스마트폰이나 컴퓨터에서 음성인식 비서프로그램 이나 번역 앱을 경험하면서 자연언어 처리기술을 접하게 되었고, 언 어 분석에 처리할 수 있다면 하는 기대가 있었다. 발화 분석에서 분 석의 객관성과 신뢰성이 문제점으로 지적되었던 것을 비추어볼 때 이런 부분을 자연언어처리(Natural Language Processing) 기술을 활용한다면 상당부분 문제가 해결될 것으로 보고 이를 언급하고 있었다. 영역 별로 보면 화용 영역보다는 어휘나 구문에서도 좀더 확실하게 자동화된 프로그램이 많은 역할을 할 수 있을 것으로 기 대하였다.

- 그거는 아까 그 컴퓨터 프로그램하고 비슷한 것인데 어쨌든 
대부분 그리고 임상에서 치료사들이 교차로 검증을 하는 것 이 아니라 혼자 하다 보면 틀릴 수 있는데 그걸 컴퓨터가 보완 을 해줄수 있다고 하면. (S1)

- 뭐 어휘 다양도? 그런 것들도 오히려 컴퓨터가 잘할 수 있을 것 같고요. 그 어휘들 목록을 가지고. 그리고... 기술이 많이 발 전해서 웬만한 것들은 다 개가 할 수 있을 것 같은데요. (S1)

- 구문이나 어휘는 충분히 도움이 될 거 같아요. 한번 해서 다 되면 다 좋을 거 같은데 치료사가 선택해서 MLU를 원하면 $\mathrm{MLU}$ 를, 어휘다양도를 원하면 어휘다양도를. (S2)

- 또래랑 비교하는 거랑 문법 같은 거나 길이 같은 것이 근데 또 사람마다 정해져 있긴 하지만 또 생각하는 것이 다른 사람들 도 있잖아요. 그러니까 딱 정해진 프로그램이 있으면 똑같은 결과가 나오니까 모든 선생님이 똑같은 결과가 나오니까. 프로 그램이 대신해주니까. 신뢰가 있으니까. 마음도 편하고. (중 략). (S5)

- 사실 프로그램이 제일 좋은 것이, 종이로 지표가 있어도 보고 선생님들마다 생각하시는 것이 다르니까 참고를 해도 보고 결 과를 내는데 차이가 있어서 저는 프로그램이 나올 수 있으면 나오는 것이 제일 좋다고 생각을 해요. (S5)

- 친구들끼리 해도 조금씩 달랐거든요. 근데 그것을 사용하면 다 똑같이 나오니까. (S5)

\section{의사소통과 담화등 화용 분석 포함}

전문가들이 발화 분석을 실시하는 이유 중 하나가 표준화 검사 로는 의사소통기능, 화용 평가가 어려워서라고 언급하였다. 그런데 의사소통기능이나 대화 등은 다른 영역에 비해 특히나 발화 수집 상황이나 분석하는 사람의 주관적인 판단이 들어갈 가능성이 많 았다. 전문가들은 그 대안으로 화용 영역의 발화 수집 프로토콜이 나 표준화된 절차, 구체적인 분석 기준을 언급하였다. 앞서 어휘, 구 문에서 언급한 컴퓨터화된 분석이 화용 영역에서는 적용되기 어려 울 것이라고 전망하면서도 혹시 화용 영역의 분석도 자연어처리기 술 적용이 가능한지 어느 정도 기대를 하는 모습을 보였다. 어휘나 문법에 비해 화용은 비언어적인 행동 분석이 포함되어야 하거나 억 양, 비유언어나 동음이의어 처리 등으로 앞서의 컴퓨터화된 언어 분석에서의 자동화되고 기계적인 분석이 어려울 것으로 언급하였 다. 그러나 시리나 빅스비 등의 자연어처리 기술에 기반한 음성인식 비서를 사용한 경험에 비추어 대화 분석도 가능할지 궁금해 하기 도 하였으며, 부분적으로 가능하다면 1 차 분석 후 평가자가 재확인 하는 정도로라도 가능했으면 하는 기대를 언급하였다.

- 다른 화용 기능 같은 것들은 그것을 잘 모르겠고. 그거는 아
무래도 그 상황에서 판단하는 것이 중요하기 때문에 특히 아 동들 같은 경우에 그 상황에서 몸짓이나 그런 것들이 동반될 수도 있고. (S1)

- 문법형태소를 잘 못 써서 이런 걸 만약에 개가 체크를 해준다 면요. 그런 걸 잘하지만 예로 들어서 ‘바위 크다’ 이런 의미를 관용어구니깐 이런 게 만약에 한다면 그거는 치료사가 이거 는 오류가 아니고 관용어니깐. (S8)

- 그 행동으로도 할 수 있었고 주제변경이 갑자기 일어나더라도 적절하게 바꿨을 수도 있는데 컴퓨터는 표면적인 거만 확인을 하니 그게 잘 안되지 않을까 생각이 조금 들어요. (S8)

- 만약에 ‘목소리가 맑다’ 이렇게 하면 저희는 그 의도가 목소리 가 청아하다라는 표현인데 컴퓨터는 그런 걸 잘 알까? 틀렸다 라고는 이 어휘는 잘 못써서 틀렸다고 할 수 있지 않을까? 라 는 생각이 지금 드는 거 같아요. (S8)

- 기능 분석할 때는 상황이 맥락이 아주 중요하잖아요. 그거는 사실은 음성 파일로만은 파악할 수 없을 거라고 보거든요. 그 니깐 그거는 동영상이 들어가야 하는데, 상황이 들어가야 하 는데 그걸 컴퓨터가 인식할 수 있을까 순간 그런 생각이 드네 요. 그니깐 그런 인토네이션이라고 하잖아요, 초음절적인 자 질을 캐치할 수 있을까? 잘했어 이런 거. (S7)

- 화용 기능에 대해서 분석을 그런 것이 되면 참 좋겠어요. 대화 를 딱 넣었을 때 애가 어떤 부분에 특별히 어려움이 있는지가 분석적으로 딱 나와주면 그거는 어머님들이 가장 사실 우리 애가 왜 이렇게 대화가 안 되고, 다른 소리를 하고 그러면 어떤 영역에서 특별히 어려움이 있으니까 애가 그 부분이 어렵고, 뭐가 안 되는 것 이런 것들이 조금 이렇게 따 나와주면 나름 애에 대해서 전반적으로 분석이 되는 거잖아요. 자발화로. 그 렇게 되면 좋기야하겠죠. (S3)

\section{결과 해석}

영역별 결과 비교 규준, 준거 마련

발화 분석의 필요성에도 불구하고 널리 실시되고 있지 못한 것은 단순히 시간과 노력이 많이 들기 때문도 있지만 힘들게 실시한다 하 더라도 분석 결과가 객관성, 신뢰도 면에서 부족한 주관적 관찰 기 술이라는 점도 몇 차례 언급되었다. 이 때문에 양육자나 다른 전문 가들에게 줄수 있는 명확하고 객관적 정보, 즉 비교 규준을 만드는 것이 필요하다고 보고 있었다.

- 연령 규준 뭐 어떤 수준인지.. MLU라든지 화용이라든지 다 규준이 들어가야 되는 건데 그런 규준들을 지금 현재 다 가지 고 있는 것 같진 않아서.. 그 규준을 만드는 것도 굉장히 어려 
운 일일 것 같은데요? 방대한 샘플을 모아야 하니까. (S1)

- 약간 공식검사 보면 또래와 비교되어 있잖아요. 그런 것이 있 었으면. (S5)

- (표준화검사의 경우) 점수만 나오면 학년지수라든지 표준점 수라든지 다 나오니깐 편하기는 하더라구요. 그렇게 되면 좋 을 거 같은데요. (S8)

- 자동으로 전사된 것들을 분석한다면 업무시간이 좀 더 줄지 않을까 그러고 또 데이터가 모이다 보면 조금 평균이라던가 그 런 자료들이 많이 모여서 그걸로 조금 더 구체적으로 아이를 파악할 수 있게. (S2)

- 사실 그 뭔가를 어머님께서 이런 부분을 또래 아이들에서는 이런데, 애는 이런 정도로 표현을 한다고 설명을 해드려야 하 는데.. 어쨌든 그런 것도 뭔가 자발화를 하면서 일반 아이들의 표준은 이런 식으로 다양하게 나오는데 언어가 느린 아이들 은 이 정도로 표현하는 것이 느리다는 것을 아셔야 하는데.. 애 가 지금 또래 규준에 비해서 지금 이런 관계들을 사용하는 것 에 있어 굉장히 제한되어 있다. 근데 그게 애가 한 말을 가지고 분석한 것이니까 엄마들이 사실 그것에 대해서 반박하기는 사실 힘든 부분이잖아요. (S3)

- 분석의 기준 같은 것들이 좀 공통화 부분이 들어가 있어야 하 지 않을까. 언어의 의미, 구문, 화용적인 측면에서 분석할 것에 대한.. 아까 말한 MLU라던가 의사소통 의도의 기준도 있어야 할 거 그런 것들? (S4)

\section{객관적이고 신뢰도 높은 결과보고서 제공}

전문가들은 발화 분석 결과를 표준화 검사의 결과들처럼 규준 과 비교한 객관적 비교 수치를 언급할 수 있었으면 좋겠다고 언급 하였다. 또한 최근 웹 상으로 결과 처리를 하는 표준화 검사들처럼 발화 분석 결과를 그래프나 표 등 시각적인 자료가 포함된 보고서 로 제공할 수 있는 프로그램이 있었으면 활용도가 높을 것으로 전 망하였다.

- 지금 막상 어떤 건진 잘 모르겠지만, 어떤 식으로든 그것들을 객관화해서 말할 수 있는 자료들이 있다면 충분히 도움이 될 거 같습니다. (S2)

- 그게 뭔가 쫙 나와서 누군가에게 데이터로 보여주기가 편하고 그게 뭐 누군가에게 상담 자료, 신뢰도가 높은 자료. (S3)

- 그게 뭔가 이렇게 물론 그게 종이에 딱 나와서 우리가 체크해 서 '애가 어느 정도이다'라고 보여드리면 되긴 하지만 뭔가 그 렇게 나오면 엄마들한테 보여드리기가 더 좋기는 하죠. (S3)

- 여튼, 뭔가 예쁜 프린트물로 나오면 고급스러워 보이잖아요..
그게 편했었거든요. 왜 이것도 만약에 그런 정도로 결과물까 지 나오면, 결과물이 나오지 않으면 신뢰도가 훅 떨어지는 것 같아요. 선생님들이 많이 안 하는 이유가, 저도 많이 안 하고 하는 이유가 REVT, PRES에 비해 시간은 많이 드는데 결과물 은. (S6)

- 서류 한 장이나 두 장처럼 나오면 좋을 거 같아요. 근데 분석 을 어떻게 했는지 세세한 그것도 나왔으면 좋겠어요. (S8)

\section{결과 활용}

결과에 기반한 중재 지침 제공

발화 분석 절차나 프로그램, 분석 방법이 체계적으로 표준화되 고 연령 별 아동 자료가 축적되어 규준이나 기준이 마련되고 나면 발화 분석 결과로 아동이 어떠한 수준이나 발달 단계에 있는지 진 단할 수 있었으면 하는 바램을 나타냈다. 특히 낱말, 문장 길이에 따 른 기존의 언어발달 단계 외에 영유아기의 의사소통 발달단계를 보 다 세분화 하여 진단, 판정해 줄 수 있었으면 하는 바램을 나타냈다.

- 영유아용에 조금 그런 것 같은데. 2 어구 이상의 발화? 이렇게 이렇게 가는 거랑 2어구 미만으로 단계를 세분화해서 '이 정 도면 아직 음절성 옹알이 단계입니다'라고 나오는. 그러니까 지금 예를 들어서 MLU 2. 얼마면 ‘몇 개월 수준입니다'라고 나오잖아요. 그런데 더 밑에 수준도 나오면 좋겠다. 이쪽에 대 한 커버가 너무 약하니 제가 현장에서 느끼는 이쪽의 아이들 은 많이 오는데 이쪽에 아이가 오든. 영유아, 발화 전 단계의 영유아. 그러니까 구어 전 단계의 영유아가 오든 구어 단계의 영유아가 오든 선생님들은 거의 동일한 느낌으로 대하게 되 는 거죠. (중략) 2 세 미만의 아이들에게서 이런 단계를 이렇게 가는 것이 좋고 이런 것이 많이. (S6)

표준화 검사에 비해 발화 분석이 중재 목표를 수립하거나 중재 결과 진전을 확인하고 목표를 조정하는데 도움이 될 수 있음을 고 려하여 전문가들은 발화 분석의 절차나 분석 방법 등이 구체적이 고 이해하기 쉬운 내용으로 구성되어 있으면 좋겠다는 희망을 언급 했고, 발화 분석의 결과가 중재에 활용하기 좋은 형태로 제시되어 '이런 정도의 분석 결과를 보이는 아동에게는 이러한 중재가 권고 된다는 등의 구체적인 중재지침이 있으면 하는 기대를 나타내었다.

- 그리고 그 분석 결과가 물론 그것을 세밀하게 결과가 나오는데 결과에 대한 설명이 사실. (중략) 지침서를 보면 무슨 말인지 하나도 모르겠는 지침서가 사실은 저는 있어요. (중략) 그 지침 서 결과 해석을 치료사가 딱 봐서 이해하기 쉽게 결과가 되어 야 할 것 같아요. 지침이 되게 세밀하지 않으면 그것을 사실 대 
강 이해하고 대강 사용할 수도 있어서 그거는 지침서를 할 때 잘 해주셨으면 좋겠어요. (S2)

- 이 아이가 오류를 많이 보이는 거 위주로 순위를 정해가주고 치료에 장기목표에 넣을 수 있겠죠, 아니면 오류들을 모아서 구조화시켜서 영역별로 목표를 짜도 될 거 같고. (S7)

영역 별오류분석제공

연구 참여 전문가들은 앞서 결과보고서에 객관적으로 또래 비교 규준이나 준거 비교가 가능해야 한다는 것과는 별개로 구체적인 분석 양상을 영역 별로 아동의 수행이나 오류 양상을 요약, 제시하 는 것이 필요하다고 언급하였다. 결과 제시 후 뒤에 그 결과가 어떻 게 나오게 되었는지, 분석을 어떻게 했는지 세부적인 분석 내용이 세세리 기록, 제시되기를 바라고 있었다.

- 오류 분석 우리 아이들은 자발화를 이렇게 사용해도 틀린 발 화를 많이 사용하잖아요. 문법형태소라든지 아니면 첨가를 한다든지 그래서 오류 분석이 들어가면 좋을 거 같아요. 격조 사중에서도 이 아이가 어떤 조사를 이 애가 틀리는 경향이 있 다 이런 것들. (S7)

- 조음에도 보면 음성을 분석해주는 것이 나왔는데. (중략) 근 데 국제음성기호대로만 하면 개가 음운변동 뭐 자음정확도? 뭐 이런 것이 도표로 해서 다 나오거든요? (S6)

- 만약에 녹음으로 이렇게 되면 그냥 자동으로 애가 애기하는 것이 들어가는 거잖아요? 그러면 애가 조음 오류가 어느 정도 인지도 알 수 있을까요? 그러면 어머님들이 이제 애가 약간 발 음이 나쁜데 사실 단어에서는 그렇게 상관이 없는데 일반적 으로 애기할 때 명료도가 많이 떨어지는 아이들은 뭔가 체킹 이 되고 그러면 사실은 뭐 한 번의 자발화 분석을 통해서 여러 가지 이점을 체크 해볼 수 있는 거니까 그건 되게 좋을 것 같 아요.(S3)

발화 자료 누적으로 언어발달 연구 및 치료사 역량강화에 기여 연구 참여자들은 발화 분석 절차가 표준화되고 영역별 규준이 마련되면 자료가 누적 수집되고 비슷한 연령대, 장애, 문제별 아동 을 비교하거나 진전사항을 객관적으로 손쉽게 확인할 수 있어서 이를 통해 최종적으로는 언어재활사들의 교육 시에도 활용 가능하 고 전문가 역량 향상에도 기여할 것으로 전망하였다.

- 그 비슷한 아이들 이렇게 옛날의 개랑 비슷한데 그 선생님은 이렇게 치료했네? 라고 보기도 하고. 컴퓨터 자발화 분석을 하 려면 근데 백업이 항상 문제가 될 것 같아요. (S6)

- 발화분석 자료 저장되서 전후 비교가 되겠죠? (S3)
- 자발화 분석을 하는 것은 치료 진단에 치료사의 역량을 계속 올리는 것이 좋은 것 같아요. 보는 관점이 자꾸 세밀해지는 거 니까. (S6)

\section{논의 및 결론}

본 연구는 아동언어장애 전문가들을 대상으로 아동 언어표본 분석에 대한 필요성이나 인식, 나아가 발화 분석과 관련된 경험에 대한 전문가 인터뷰를 실시하고, 인터뷰 자료를 분석하여 아동 발 화 분석의 과정 별로 개선 요구사항, 대안이 될 만한 주제를 도출하 였다.

\section{발화 분석의 필요성}

연구에 참여한 전문가들은 발화 분석에 대한 중요성과 실시의 필요성에는 전반적으로 동의하였다. 현재 사용되고 있는 표준화검 사는 의사소통기능이나 화용 영역의 평가 항목이 충분히 포함되어 있지 않아 의사소통 평가가 중요한 영유아의 경우 표준화검사만으 로는 제대로 된 진단이 어렵다고 보고하였다. 또, 영유아나 장애를 동반한 아동들을 표준화검사에 적응하는 데에 어려움이 있다는 문제도 제기되었다. 실제로 익숙하지 않은 과제로, 검사 자체를 거 부하거나 치료 시간에 관찰되는 언어 행동이 표준화검사의 질문과 그림 자극 유도에서는 나타나지 않는 경우도 자주 언급되었다. 해 외 미숙아 연구에서도 일반 아동에 비해 낮은 언어능력이 표준화 검사보다는 언어표본분석에서 더 잘 드러났다고 보고되기도 하였 다(Imgrund, Loeb, \& Barlow, 2019). 이러한 이유 때문에 상당수의 전문가들이 의외로 발화 분석을 실시하는 주된 연령대가 영유아기 라고 보고하였고, 발화 분석에서 주로 관심을 두거나 분석하는 영 역은 의사소통기능이나 화용 영역이라고 보고하였다. 이러한 언급 은 최근 임상현장에 영유아 사례가 많아진 영향도 있지만 발화 분 석이 발화 길이나, 문법 형태소 사용 등의 구문형태론적인 분석 위 주였던 것이 최근에는 의사소통기능이나 상호작용을 중시하기 때 문으로 볼 수도 있는데 어떤 경우라 하더라도 의사소통기능을 체 계적으로 관찰하고 분석할 수 있는 발화표본 수집 절차나 분석 체 계 등에 대한 요구가 크다는 점은 공통적이었다.

대상자의 실제 언어수준을 잘 반영하기 때문에 표준화 검사를 보완하기 위하여 발화 분석이 필요하다는 입장은 성인 신경언어장 애를 주로 담당하는 언어재활사를 대상으로 한 연구와도 동일하였 으며(Yoon, Oh, \& Lee, 2020), 언어표본분석에서 화용적 측면을 주 로 분석한다는 점은 최근 실시된 대규모 설문조사에서와 일치하는 결과라고 볼 수 있다(Lee et al., in press). 
표준화검사에서 상대적으로 같은 언어수준을 보인다 해도 실제 로 어려워하는 부분은 상당히 다를 수 있어서 표준화검사가 언어 문제의 유무 판별에는 도움을 줄 수 있지만 이후 중재를 계획하는 경우에는 별 도움이 되지 않는다는 점도 문제로 제기되었다. 언어 능력의 양적인 평가는 가능하지만 구체적, 질적인 양상의 파악이 어렵다는 것은 표준화검사의 제한점으로 여러 문헌에서 언급되던 것인데 현장 전문가의 언급으로 다시 확인되었다고 볼 수 있으며, 중재에 대한 계획이나 기초선 수행을 확인하기 위해 발화 수집과 분석이 필요한 근거라고 할 수 있다. 더 나아가 표준화검사의 강점 중 하나인 상대적인 비교 면에서도 현재 검사도구들의 경우에는 진 단의 정확성 문제가 대두되었다. 연구 참여자들은 검사도구의 출 판 이후 업데이트가 이루어지지 않아 규준이 최근 아동들을 진단 하기에 부적절하거나 언어장애 판정기준이 너무 엄격해서 실제로 는 언어치료의 도움을 받는 것이 권고되는 아동임에도 표준화검사 결과로는 지연이나장애 진단이 나오지 않는 경우가 있다는 문제를 제기하였다. 이러한 경우 면담 참여자들은 그 대안으로 아동의 실 제 발화를 관찰, 분석한 것으로 보호자들에게 치료를 권고한다고 하여 발화 분석이 치료 결정에 도움이 될 수 있음을 언급하였다.

\section{발화 분석의 실시 현황과 한계점}

본 연구 참여자들은 발화 분석 실시의 필요성에 대해서는 전반 적으로 동의하고 있음에도 불구하고 실제 현장에서는 이를 많이 활용하고 있지 못하는 상반된 경향을 보였다. 학교 근무 언어재활 사를 대상으로 한 해외 선행연구에서도 대다수의 언어재활사가 제 한적인 경우에만 언어 분석을 실시한다고 보고된 바 있는데 본 연 구의 결과도 이에 일치하는 결과라고 볼 수 있다. 선행연구에서는 $67 \%$ 의 언어재활사가 언어표본분석을 사용한다고 대답하였으나 이들 중 과반수는 일년에 10 개 미만의 표본을 분석한다고 보고하 였다. 즉, 3 명의 1 명 꼴로는 언어 분석을 전혀 실시하지 않았으며, 실 시하였다는 응답자들 중 반 이상은 매우 제한적으로 사용하였다 고 보고하였다(Pavelko et al., 2016). 본 연구 참여자 또한 치료나 다 른 평가 과정에서의 제한적 발화를 즉시 전사하여 분석해 보거나 특정 대상자에게 한정해서 언어표본분석을 실시한다고 보고하였 다. 언어평가에서 발화 분석을 사용하지 않는다는 이유로 가장 많 이 언급된 것은 발화의 수집과 분석에 많은 시간과 노력이 소요된 다는 점이었다. 이는 국내 언어재활사 대상 설문연구(Lee et al., in press)나 성인 신경언어장애 환자를 주로 담당하는 언어재활사를 대상으로 한 질적 연구(Yoon et al., 2020)에서 언어표본분석을 실 시하지 않는 이유와 동일한 결과이며, 해외에서의 언어표본분석 사용에 대한 선행연구 결과와도 일치한다(Baker, 1988; Kemp \&
Klee, 1997; Pavelko et al., 2016).

특히 본 연구에서는 병원 세팅의 경우 검사나 평가 항목별로 수 가가 정해지는데 발화 분석은 수가에 반영되지 않는다는 점도 발 화 분석을 실시하지 않게 되는 이유로 언급되었다. 또한 중재로 이 어지는 것이 전제되지 않은 초기 평가가 상대적으로 많은 병원 세 팅의 경우에는 아동을 충분히 관찰하고 발화를 수집할 시간이 특 히 부족하다는 문제가 더욱 부각되었다. 발화 수집이 가능하다고 해도 분석에 필요한 충분한 발화량을 확보하기가 힘들고 수집하는 상황이나 절차도 아동과 상황에 따라 달라지는 등의 제한적, 임의 적 표집 절차로 인해 분석 결과에 대한 신뢰도 활용도가 표준화 검 사에 비해 떨어진다는 점도 문제로 제기되었다.

수집한 발화를 분석하는 과정에서는 발화 구분이나 문법적 분 석에서 치료사들은 자신들의 분석에 대해 객관적인 근거나 확인해 줄만한 확실한 지침이 부족하다는 점을 어려운 점으로 꼽았다. 특 히 의사소통 의도의 경우에는 주관적 의견이 개입할 여지가 있어 서 발화 분석에 있어서 객관성과 정확성에 대한 확신을 갖지 못한 다고 보고하였다. 분석 결과를 해석할 때도 결과를 비교할 규준이 마련되어 있지 않은 것은 표준화검사와 비교했을 때 발화 분석의 가장 큰 문제로 지적되었다. 결과가 무엇을 의미하는지 참조할 준거 와 규준이 부족하여 발화 분석 결과는 표준화검사 결과에 덧붙여 아동의 말이나 행동을 기술하는 정도로 사용할 뿐, 표준화검사의 결과처럼 이를 근거로 중재를 권유하거나 진단을 내리는 것은 어렵 다고 문제를 제기하였다. 이에 비해 표준화검사는 보고서에 제시할 만한 객관적인 수치나 규준에 근거한 비교 결과를 제공함으로써 아동의 언어능력이 어느 수준인지 쉽게 전달할 수 있게 되어 보호 자와 다른 전문가들이 중재 권유를 받아들일 수 있게 하는 등의 중 재 관련 결정을 하는데 발화 분석에 비해 유리하다고 보고하였다.

아동 언어를 직접 관찰, 분석하는 것은 표준화검사에 비해 치료 계획을 세우는데 강점이 있다고 언급되어 왔다. 하지만 표집, 분석, 결과 해석에서의 문제들이 누적되면서 현재 언어치료 임상현장에 서는 발화 분석 결과를 바탕으로 치료 계획을 수립하는 것이 쉽지 않다고 보고되었다. 초기 구어 수준 아동의 경우 한 낱말 발화 수 준이면 한두 낱말이 추가된 형태의 발화나 두세 낱말 조합을 중재 목표로 할 수 있지만 아직 구어 발화가 많지 않은 영유아의 경우나 언어발달 초기 이후 학령기 이후의 구문이나 문법형태소 발달 양 상은 체계적인 자료 수집을 통한 연구 결과가 부족하여 발화 분석 결과를 기반으로 한 중재 계획으로 이어지기 어렵다고 보고되었다. 표준화된 표집, 분석체계 마련과 더불어 분석 결과 축적을 통해 구 체적인 발달 순서나 양상이 파악되고 준거가 마련되어야 한다. 


\section{발화 분석에 대한 개선점과 대안}

본 연구에서 전문가들의 견해를 종합하여 발화 분석에 대한 현 실적 제약을 극복하고 대안적 평가 모형으로 개선해나가기 위하여 도출된 주제는 다음과 같다.

첫째, 표집 과정에서는 발화 수집 방법과 절차를 체계화, 표준화 하여 발화 분석에 대한 접근성과 결과 처리의 객관성과 신뢰도를 제고할 필요가 있다. 어떤 방법으로 어느 정도의 발화를 수집한다 는 일관된 지침과 함께, 연령 등을 고려한 세부 수집 절차가 체계적 으로 마련된다면 치료사들의 분석 절차에 대한 의사결정 고민을 덜 수 있어서 발화 분석을 보다 많이 실시할 수 있을 것으로 보인다. 현재는 발화를 어떻게 유도하고 어떤 상황이 어느 구문이나 어휘 유도에 유리하다는 등의 유도 전략의 개인차 때문에 치료사 간 발 화 분석 결과가 매우 다르게 나타날 수 있는 상황이었다. 다양한 발 화 수집 및 분석 절차가 표준화되어 있는 해외에서는 표준화된 발 화 수집 및 분석 절차를 사용하지 않고 임상가가 스스로 고안된 절 차를 사용하는 것은 근거기반실제(evidence based practice)에 비 추어 바람직하지 못하다고 여겨지는데 비해(Pavelko et al., 2016) 국 내에서는 표준화된 기존 발화 수집 절차를 사용하는 비율이 상대 적으로 적고(Lee et al., in press) 언어재활사가 그때 그때 다른 발화 수집 절차를 사용함으로써 분석과 결과 해석에서의 객관성과 신뢰 성이 담보되지 못하고 있는 상황이다.

또 연구 참여자들은 컴퓨터를 이용한 소프트웨어나 휴대폰 앱 등으로 앞서의 지침 하에 발화 수집 과정을 관리할 수 있다면 치료 실뿐 아니라 일상생활에서의 대표성 있는 발화를 보다 손쉽게 수 집하여 분석할 수 있을 것으로 언급하였다. 이와 더불어 현재 휴대 폰 음성인식 비서서비스에 사용되는 음성인식기술 등을 적용하여 완전한 수준까지는 아니어도 초벌 자동 전사 후 평가자가 확인 보 완하는 시스템이 갖추어진다면 표집 과정에서의 시간과 노력이 매 우 절감될 것으로 기대하였다. 해외에서는 아동의 일상생활에서의 발화를 폭넓게 수집, 기록하고 자동으로 전사해주는 소프트웨어 가 점차 상용화되어 사용되고 있으며(Pezold, Imgrund, \& Storkel, 2020), 이미 오래전부터 컴퓨터 프로그램을 이용하여 전사 시간을 줄이는 것이 권고되었다(Kemp \& Klee, 1997). 최근에는 자동 전사 의 정확도를 검증하는 연구와 수동 전사한 결과와 비교하는 연구 또한 활발히 진행되고 있다(Busch, Sangen, Vanpoucke, \& Wieringen, 2017; Canault, le Normand, Foudil, Loundon, \& Hung, 2016).

두 번째, 분석 과정에서는 객관적이고 정확한 분석이 이루어질 수 있는 분석 체계의 마련이 시급한 것으로 평가되었다. 분석의 정 확도나 수준이 평가자 개인의 역량에 전적으로 의존하고 있다 보니 아직 경력이 짧고 노하우가 부족한 언어재활사들의 경우 분석에 어
려움이 있을 수 있고, 의사소통행동의 경우 같은 행동에 대한 분석 이 서로 다를 수 있다는 문제가 제기되었다. 이러한 문제들은 발화 표본분석의 어려운 점으로 문헌들에서 언급되어 오던 것으로 본 연구의 참여자의 면담 내용에서도 재확인되었다고 볼 수 있다 (Pavelko et al., 2016; Haynes \& Pinzola, 2017). 해외의 선행연구에 서도 훈련과 전문성 부족이 발화 분석의 장애물 중 하나로 언급되 었고(Kemp \& Klee, 1997), 최근 국내 설문연구에서는 언어재활사 의 교육수준과 자격증 급수에 따라 언어표본 분석 실시 비율이 달 라짐을 보고하였다(Lee et al., in press). 이러한 한계를 보완하기 위 해서는 재활사 대상 앞서의 표준화된 발화 수집 절차에 이어 구체 적이고 명확한 분석 지침이 제시되는 표준화된 분석체계의 개발이 필요하다. 영어권의 경우 이미 문법이나 어휘, 발화 차례 등을 분석 하는 다양한 분석체계가 개발되고 컴퓨터화되어 상용화되어 왔다. 특히 구문 문법 영역의 경우 Ipsyn이나 DSS나 LARSP과 같은 다양 한 분석 체계 중 과제나 대상자의 연령을 고려하여 선택하여 사용 할 수 있으며 CLAN과 SALT는 전반적인 언어학적 분석을 지원하 고 있다. 국내에서도 자연언어처리 분야에서는 한국어 형태소를 분 석하는 분석기들이 다양하게 개발되어 있고 이를 이용한 연구도 활발히 진행되고 있다. 이 중에서는 꼬꼬마(KKMA)나 KoNLPy처 럼 오픈 소스로 공개되어 있는 것들이 많이 있는데(Park \& Cho, 2014) 아직까지 언어치료 분야에서는 알려지거나 사용되지 않아서 본 연구의 응답자들은 컴퓨터로 분석을 할 수 있지 않을까 하고 막 연히 기대하면서도 막상 그렇게까지 자동적으로 발화를 분석하는 것은 어려울 것 같다는 언급이 많았다. 이러한 표준화된 분석체계 와 함께 그 분석체계를 활용함에 있어 대상자의 연령이나 장애 영 역 별로 어떠한 분석 항목을 포함할 것인가에 대한 후속 연구가 진 행될 필요가 있다.

셋째, 발화 분석 자료를 축적을 통해 발화 분석 결과를 비교할 수 있는 규준이나 발달 단계를 분류할 수 있는 준거 참조 기준의 마련 이 필요하다. 언어표본을 수집하고 분석하는 과정이 표준화된다면 같은 체계로 수집, 분석된 발화 자료를 축적하여 이를 바탕으로 규 준이나 발달 단계를 구분할 수 있는 준거 참조 기준에 대한 연구가 가능할 것이다. 전사나 분석에서 컴퓨터화된 언어처리 기술의 가장 대표적인 컴퓨터 언어분석 프로그램인 SALT (Miller \& Iglesias, 2015)의 경우 초기 개발 이후 지속적으로 데이터를 누적하여 규준 을 개정하여 왔으며 최근에는 30년간 3-18세 대상자들의 수천 개 발화 샘플을 규준 데이터베이스에 포함시켜 청소년의 발화표본분 석 자료로 구어산출을 분석, 평가할 수 있게 되었다(Miller et al., 2016). 이러한 발화 분석에서의 영역 별 규준 자료가 만들어진다면 참여자들이 언급한 대로 '표준화 검사 결과의 보고서처럼 표나 그 
래프 등의 객관적, 시각적 자료로 아동의 언어능력을 보고'할 수 있 게 될 것이며 누적된 자료는 임상현장뿐 아니라 영유아기부터 청소 년, 성인기까지 영역별 언어발달 양상 연구에도 활발히 사용될 수 있을 것이다. 특히, 국내에서는 학령 전기에 비해 학령기 이후의 구 문이나 화용 발달 양상은 연구결과나 자료가 매우 부족한 수준인 데 이 연령대 발화 자료가 충분히 확보된다면 전 생애 언어발달에 대한 이해를 향상시키는 데에도 기여할 것이다.

본 연구에서는 아동언어장애 전문가들의 언어표본분석에 대한 인식을 알아보고 평가에서의 언어표본분석이 활용 현황과 그 과정 에서의 어려움과 해결 방안을 심층 인터뷰를 통해 알아보았다. 발 화 분석은 여러가지 장애요인으로 폭넓게 사용되고 있지는 못하지 만 평가도구로서 중요한 가치를 가지고 있다고 인식되었으며, 현재 임상현장에서 이를 보편적으로 사용하고 평가 과정에서 보다 편리 하고 신뢰도 높은 절차로 활용되려면 표집이나 분석체계가 체계화, 표준화, 최종적으로는 자동화되어야 하고, 이러한 표집, 분석체계 로 수집·분석된 자료를 축적함으로써 연령별, 영역별 언어발달에 대한 모형을 갖추어 나가야 한다. 본 연구는 소수의 전문가들을 심 층 면담하여 발화 분석에 대한 견해를 탐색적으로 살펴보고 깊이 있게 분석해 보았다는데 의의가 있으나 참여자가 소수였다는 한계 가 있다. 이후에는 대규모 설문 연구 등으로 본 연구 결과를 재확인 하고 발화 표본 수집과 분석의 구체적인 표준화 내용이나 방향에 대해서는 집단 비교 연구 등의 실험 연구로 뒷받침되어야할 것이다.

\section{REFERENCES}

Baker, L. (1988). The use of language sample analysis- results of questionnaire. Bulletin of the College of Speech Therapists, 2-4.

Betz, S. K., Eickhoff, J. R., \& Sullivan, S. F. (2013). Factors influencing the selection of standardized tests for the diagnosis of specific language impairment. Language, Speech, and Hearing Services in Schools, 44(2), 133-46.

Bloom, L., \& Lahey, M. (1978). Language development and language disorders. New York, NY: Wiley.

Busch, T., Sangen, A., Vanpoucke, F., \& Wieringen, A. van. (2017). Correlation and agreement between Language ENvironment Analysis (lenaTM) and manual transcription for Dutch natural language recordings. Behavior Research Methods, 50(5), 1921-1932.

Canault, M., le Normand, M. T., Foudil, S., Loundon, N., \& Hung, T. V. (2016). Reliability of the language environment analysis system (lena (tm)) in European French. Behavior Research Methods, 48, 1109-1124.

Crystal, D., Fletcher, P., \& Garman, M. (1989). Grammatical analysis of lan- guage disability (2nd ed.). London: Whurr.

Evans, J. L. (1996). Plotting the complexities of language sample analysis: linear and non-linear dynamical models of assessment. In K. Cole, P. Dale, \& D. Thal (Eds.), Assessment of communication and language (pp. 207-256). Baltimore, MD: Brookes.

Finestack, L. H., Rohwer, B., Hilliard, L., \& Abbeduto, L. (2020). Using computerized language analysis to evaluate grammatical skills. Language, Speech, and Hearing Services in Schools, 51(2), 184-204

Ha, S., Seol, A., So, J., \& Pae, S. (2016). Speech and language development patterns of Korean two-year-old children from analysis of spontaneous utterances. Communication Sciences \& Disorders, 21(1), 47-59.

Han, W., \& Yim, D. (2016). Relationship among complex sentence production, implicit learning, and working memory based on structural priming method in children with specific language impairment. Communication Sciences \& Disorders, 21(4), 590-604.

Haynes, W., \& Pinzola,, R. (2017) . Diagnosis and Evaluation in Speech Pathology (Kim et al., Trans). Seoul: Hakjisa.

Heilmann, J., Miller, J. F., Iglesias, A., Fabiano-Smith, L., Nockerts, A., \& DigneyAndriacchi, K. (2008). Narrative transcription accuracy and reliability in two languages. Topics in Language Disorders, 28(2), 178-188.

Imgrund, C. M., Loeb, D. F., \& Barlow, S. M. (2019). Expressive language in preschoolers born preterm: results of language sample analysis and standardized assessment. Journal of Speech, Language, and Hearing Research, 62(4), 884-895.

Kemp, K., \& Klee, T. (1997). Clinical language sampling practices: results of a survey of speech-language pathologists in the United States. Child Language Teaching \& Therapy, 13(2), 161-176.

Kim, Y. (2014). Assessment and intervention of child language disorders. Seoul: Hakjisa.

Korean Institute for healthy family. (2012). Result report of language development support project for children of multicultural families. Seoul: Author.

Lee, L. L. (1974). Developmental sentence analysis: a grammatical assessment procedure for speech and language clinicians. Evanston, IL: Northwestern University Press.

Lee, Y., Oh, S., Yoon, J., \& Choi, J. (in press). Attitude to Korean speech-language pathologists toward usage of language sample analysis and computer-aided LSA. Communication Sciences \& Disorders.

Lincoln, Y. S., \& Guba, E. G. (1985). Naturalistic inquiry. Beverly Hills, CA: Sage.

MacWhinney, B. (2000). The CHILDES project: tools for analyzing talk (3rd 
ed.). Mahwah, NJ: Erlbaum.

McCabe, A., \& Champion, T. (2010). A matter of vocabulary II: low-income African American children's performance on the Expressive Vocabulary Test. Communication Disorders Quarterly, 31(3), 162-169.

Mexwell, J. A. (2004). Qualitative Research Design: Interactive approach. (M. S. Lee, C. M. Kim, \& M. H. Ko, Trans.) Seoul: Gunja Publishing. (Original work published 1996).

Miller, J. F. (1981). Assessing language production in children: experimental procedures. Boston, MA: Allyn \& Bacon.

Miller, J. F., Andriacchi, K., \& Nockerts, A. (2016). Assessing language production using SALT software: a clinician's guide to language sample analysis (2nd ed.). Madison, WI: SALT Software.

Miller, J. F., \& Iglesias, A. (2015). Systematic Analysis of Language Transcripts [Computer software]. SALT Software, LLC.

Nelson, N. W. (2009). Language and literacy disorders: Infancy through adolescence. Upper Saddle River, NJ: Pearson.

Nippold, M. A., Frantz-Kaspar, M., Cramond, P., Kirk, C., Hayward-Mayhew, C., \& MacKinnon, M. (2014). Conversational and narrative speaking in adolescents: examining the use of complex syntax. Journal of Speech, Language, and Hearing Research, 57(3), 876-886.

Owens, R. E. (2014). Language disorders: a functional approach to assessment and intervention (6th ed.). Upper Saddle River, NJ: Pearson.

Pae, S. (2000). Korean Utterance Analysis 2.0 (Korean Computerized Language Analysis: KCLA 2.0): Manual for use. Seoul: Paradise Welfare Foundation.

Park, E., \& Cho, S. (2014). KoNLPy: easy and concise Korean information processing Python package. Proceedings of the 26th Korean and Korean Information Processing Conference, 1-4.

Paul, R., \& Norbury, C. (2012). Language disorders from infancy through adolescence (4th ed.). St. Louis, MO: Mosby.

Pavelko, S. L., Owens JR, R. E., Ireland, M., \& Hahs-Vaughn, D. L. (2016). Use of language sample analysis by school-based SLPs: results of a nationwide survey. Language, Speech, and Hearing Services in Schools, 47(3), 246258.

Pavelko, S. L., \& Owens, J. R. E. (2017). Sampling Utterances and Grammati- cal Analysis Revised (SUGAR): new normative values for language sample analysis measures. Language, Speech, and Hearing Services in Schools, 48(3), 197-215.

Pezold, M. J., Imgrund, C. M., \& Storkel, H. L. (2020). Using computer programs for language sample analysis. Language, Speech, and Hearing Services in Schools, 51(1), 103-114.

Scarborough, H. (1990). Index of productive syntax (IPSyn). Applied Psycholinguistics, 11(1), 1-22.

Scott, C. M., \& Windsor, J. (2000). General language performance measures in spoken and written narrative and expository discourse in school agechildren with language learning disabilities. Journal of Speech, Language, and Hearing Research, 43(2), 324-339

Song, H., Song, Y., \& Park, H. (2015). Characteristics of vocabulary use in narrative tasks in preschool children: a preliminary study for AAC application. Communication Sciences \& Disorders, 20(3), 386-399.

Sticker, K. R. (1987). Guide to analysis of language transcripts. Eau Claire, WI: Thinking Publications.

Strauss, A. L., \& Corbin, J. M. (2001). Basics of qualitative research (2nd ed.) (K. R. Shin, Trans.). Seoul: Hyunmoonsa. (Original work published 1998).

Xu, D., Yapanel, U., Gray, S., Baer, C.T. (2008). The LENA Language Environment Analysis System: The Interpreted Time Segments (ITS) File. Technical Report No LTR-04-2. Boulder, CO: LENA Research Foundation.

Yim, D., Park, W., Cheon, S., Lee, Y., \& Lee, J. (2015). Interaction Skills via Spontaneous Speech Sample Analysis: 2- to 5-Year-Old Children with and without Language Impairment. Communication Sciences \& Disorders, 20(3), 364-373.

Yoon, J., Oh, S., \& Lee, Y. (2020). A qualitative study on experiences and needs of language sample analysis by speech-language pathologists: focused on patients with acquired neurogenic language disorders. Communication Sciences \& Disorders, 25(2), 411-430.

Yoon, M., Kim, S., Kim, J., Chang, M., \& Cha, J. (2013). Reliable sample size for mean length of utterance analysis in preschooler. Communication Sciences \& Disorders, 18(4), 368-378. 


\section{국문초록}

\section{언어재활사의 언어표본분석 경험 및 요구에 관한 질적 연구: 아동언어장애를 중심으로}

오소정 $\cdot$ 윤지혜 $\cdot$ 이윤경

'동명대학교 언어치료청각학과, ${ }^{2}$ 한림대학교 언어청각학부

배경 및 목적: 본 연구의 목적은 언어재활사의 아동의 언어표본분석에 대한 인식이나 경험에 대한 견해를 종합하여 언어분석의 필요 성이나 현황, 어려움에 대한 면담 내용을 질적으로 분석하여 언어평가 과정에서 발화 분석을 보다 유용하게 사용할 수 있는 대안을 모 색하는 것이었다. 방법: 아동언어분석에 경험이 있는 8 명의 언어재활사가 아동언어평가 및 중재과정에서의 발화 분석의 필요성, 실시 현황과 요구에 대하여 심층 인터뷰에 참여하였다. 면담은 연구자들이 개발한 질문지에 기초하여 제 1 연구자와 개별적으로 이루어졌으 며 인터뷰 내용은 녹음하여 질적 연구의 연속적 비교법에 따라 전사, 코딩하였다. 결과: 인터뷰 내용을 전사하여 질적 분석한 결과 발화 분석의 현황에 대하여 2 개 주제와 그에 따른 8 개 소주제를 도출하였으며, 발화 분석에 대안에 대하여 4 개 주제와 그에 따른 11 개 소주 제가 도출되었다. 논의 및 결론: 전문가들은 발화분석의 필요성은 공통적으로 인식하였으나 임상현장에서 발화분석을 실시하는 데에 는 현실적 어려움이 있음을 언급하였다. 이에 대한 대안으로는 체계적인 표집 절차와 표준화된 분석 체계를 이용한 객관적 분석, 발화 자료 축적을 통한 규준 비교 등이 필요한 것으로 분석되었다. 시간과 절약하기 위하여 자연어 처리기술이 포함된 컴퓨터화된 언어분석 활용도 논의되었다.

핵심어: 언어표본분석, 아동언어, 질적 연구, 자연언어처리, 컴퓨터 언어분석

이 논문은 2019년 대한민국 교육부와 한국연구재단의 지원을 받아 수행된 연구임(NRF-2019S1A5A2A03052093).

\section{참고문헌}

김영태(2014). 아동언어장애의 평가 및 중재. 서울: 학지사.

박은정, 조성준(2014). KoNLPy: 쉽고 간결한 한국어 정보처리 파이썬 패키지. 제 26회 한글 및 한국어 정보처리 학술대회 논문집, 1-4.

배소영(2000). 한국어 발화분석 2.0 (KCLA 2.0): 활용을 위한 지침서. 서울: 파라다이스 복지재단.

송혜정, 송양민, 박현주(2015). 학령전기 아동의 내러티브 과제에서 나타나는 어휘사용 특성. Communication Sciences \& Disorders, 20(3), 386-399. 윤미선, 김수진, 김정미, 장문수, 차재은(2013). 평균발화길이 분석을 위한 발화 표본의 크기. Communication Sciences \& Disorders, 18(4), 368-378. 윤지혜, 오소정, 이윤경(2020). 언어재활사의 언어표본분석 경험 및 요구에 관한 질적 연구: 후천성 신경언어장애 환자를 중심으로. Communication

Sciences \& Disorders, 25(2), 411-430.

이윤경, 오소정, 윤지혜, 최지은(출간 중). 언어재활사의 언어표본분석 사용과 컴퓨터 보조 언어표본분석에 대한 태도. Communication Sciences \& Disorders.

임동선, 박원정, 천성혜, 이여진, 이지연(2015). 자발화 분석을 통한 만 2-5세 아동의 상호작용 기술 특성 및 언어발달지체 아동 비교 연구. Communication Sciences \& Disorders, 20(3), 364-373.

하승희, 설아영, 소정민, 배소영(2016). 자발화 분석을 통한 만 2세 한국아동의 말-언어발달 특성. Communication Sciences \& Disorders, 21(1), 47-59. 한국건강가정진흥원(2012). 다문화가족자녀언어발달지원사업 보고서. 서울: 한국건강가정진흥원.

한우주, 임동선(2016). 언어장애 아동의 구문점화 방식에 따른 복문 산출 능력과 암묵적 학습 및 작업기억. Communication Sciences \& Disorders, 21(4), 590-604.

Maxwell, J. A.(2004). 질적 연구설계: 상호작용적 접근(이명선, 김춘미, 고문희 옮김). 서울: 군자출판사(원서출판 1996). Strauss, A. L., Corbin, J. M. (2001). (질적연구) 근거이론의 단계(신경림, 옮김). 서울: 현문사(원서출판 1998). 


\section{ORCID}

오소정(제1저자, 교수 https://orcid.org/0000-0002-1427-5828); 윤지혜(공동저자, 교수 https://orcid.org/0000-0003-1403-2276); 이윤경(교신저자, 교수 https://orcid.org/0000-0002-9759-6247) 